\title{
The Political Legacy of American Slavery
}

\author{
Avidit Acharya, Stanford University \\ Matthew Blackwell, Harvard University \\ Maya Sen, Harvard University
}

We show that contemporary differences in political attitudes across counties in the American South in part trace their origins to slavery's prevalence more than 150 years ago. Whites who currently live in Southern counties that had high shares of slaves in 1860 are more likely to identify as a Republican, oppose affirmative action, and express racial resentment and colder feelings toward blacks. We show that these results cannot be explained by existing theories, including the theory of contemporary racial threat. To explain the results, we offer evidence for a new theory involving the historical persistence of political attitudes. Following the Civil War, Southern whites faced political and economic incentives to reinforce existing racist norms and institutions to maintain control over the newly freed African American population. This amplified local differences in racially conservative political attitudes, which in turn have been passed down locally across generations.

$\mathrm{F}$ or the first 250 years of American history, white landowners, predominantly from the South, enslaved millions of individuals of African descent. This "peculiar institution," as it was sometimes called, defined the social, economic, and political landscape of the American South throughout this period. Slavery was so crucial to the South that one Georgia newspaper editor wrote, "Negro slavery is the South, and the South is negro slavery" (cited in Faust 1988, 60). Yet, despite slavery's prominence in shaping American history, and despite volumes written by economists and historians on its consequences, political scientists have largely overlooked how American slavery and the events following its abolition could continue to influence the South's contemporary politics. Given recent findings on the long-term consequences of past events and institutions (Acemoglu, García-Jimeno, and Robinson 2012; Dell 2010; Nunn and Wantchekon 2011; Voigtländer and Voth 2012), it would be surprising if such a fundamental aspect of American history had no persistent impact on American politics.

In this paper, we show that the local prevalence of slavery - an institution that was abolished 150 years agohas a detectable effect on present-day political attitudes in the American South. Drawing on a sample of more than 40,000 Southern whites and historical census records, we show that whites who currently live in counties that had high concentrations of slaves in 1860 are today on average more conservative and express colder feelings toward African Americans than whites who live elsewhere in the South. That is, the larger the number of slaves per capita in his or her county of residence in 1860, the greater the probability that a white Southerner today will identify as a Republican, oppose affirmative action, and express attitudes indicating some level of "racial resentment." We show that these differences are robust to accounting for a variety of factors, including geography and mid-nineteenth-century economic and social conditions. These results strengthen when we instrument for the prevalence of slavery using geographic variation in cotton-growing conditions.

We consider several explanations for our results rooted in contemporary forces and find each to be inconsistent with the empirical evidence. For example, we consider the possibility that whites are simply more racially conservative when exposed to larger black populations-the central finding of the literature on racial threat (Blalock 1967;

Avidit Acharya (avidit@stanford.edu) is an assistant professor at Stanford University, Stanford, CA 94305; web: http://stanford.edu/ avidit. Matthew Blackwell (matt_blackwell@harvard.edu) is an assistant professor at Harvard University, Cambridge, MA 02138; web: http://www.mattblackwell.org. Maya Sen (maya_sen@hks.harvard.edu) is an assistant professor at Harvard University, Cambridge, MA 02138; web: http://scholar.harvard.edu/msen.

Data and supporting materials necessary to reproduce the numerical results in the paper are available in the JOP Dataverse (https://dataverse.harvard.edu /dataverse/jop). An online appendix with supplementary material is available at http://dx.doi.org/10.1086/686631.

The Journal of Politics, volume 78, number 3. Published online May 19, 2016. http://dx.doi.org/10.1086/686631 
Blumer 1958; Key 1949). However, when we estimate the direct effect of slavery on contemporary attitudes (Acharya, Blackwell, and Sen, forthcoming), we find that contemporary shares of the black population explain little of slavery's effects. We also test various other explanations, including the possibility that slavery's effects are driven exclusively by twentieth-century population shifts or income inequality between African Americans and whites. We find no evidence that these contemporary factors and theories of population sorting fully account for our results. Introducing individual-level and contextual covariates commonly used in the public opinion literature also does not explain away our finding.

To explain our results, we instead propose a theory of the historical persistence of political attitudes. The evidence suggests that regional differences in contemporary white attitudes in part trace their origins to the late slave period and the time period after its collapse, with prior work suggesting that the fall of slavery was a cataclysmic event that undermined Southern whites' political and economic power. For example, Du Bois (1935), Foner (2011), and Key (1949), among others, have argued that the sudden enfranchisement of blacks was politically threatening to whites, who for centuries had enjoyed exclusive political power. In addition, the emancipation of Southern slaves undermined whites' economic power by abruptly increasing black wages, raising labor costs, and threatening the viability of the Southern plantation economy (Alston and Ferrie 1993; Ransom and Sutch 2001). Taken in tandem with massive preexisting racial hostility throughout the South, these political and economic changes gave Southern Black Belt elites an incentive to further promote existing anti-black sentiment in their local communities by encouraging violence toward blacks and racist attitudes and policies (Roithmayr 2010). This amplified the differences in white racial hostility between former slaveholding areas and non-slaveholding areas and intensified racially conservative political attitudes within the Black Belt. These have been passed down locally, one generation to the next.

We provide empirical support for this mechanism by showing that areas of the South that were the earliest to eliminate the political and economic incentives for anti-black violence-for example, by adopting new technologies, such as tractors, that reduced the demand for black farm laborare also the areas in which slavery's long-term effects have most attenuated. Furthermore, as evidence for intergenerational (cultural) transfer of attitudes, we show that there exists a strong correlation between the racial attitudes of parents and their children in the US South. Our evidence, therefore, supports the theory that political attitudes have persisted historically in the US South, rather than the view that attitudes are driven exclusively by contemporaneous forces - making our position quite distinct from much of the existing public opinion literature.

The paper proceeds as follows. First, we motivate our hypothesis that historical persistence-and not just contemporary factors - shape modern-day political attitudes. We discuss our data in the next section and present our core results linking the prevalence of slavery in 1860 and contemporary attitudes in the following section, with additional robustness checks presented in the appendix, available online. We then consider and provide evidence against several competing theories rooted in contemporary factors, including the theory of racial threat. In the following section, we provide evidence for our theory of the historical persistence of political attitudes, paying close attention to postbellum political and economic incentives as the driving mechanism. We conclude by discussing the broader implications of our research for scholarship in American political behavior.

\section{EXPLAINING REGIONAL DIFFERENCES IN SOUTHERN POLITICAL AND RACIAL ATTITUDES}

We orient our analysis toward the Southern "Black Belt" (or the "Cotton Belt"), the hook-shaped swath of land that was the primary locus of antebellum slavery (fig. 1). Scholars have noted that Black Belt whites were particularly prominent in Southern politics and have been more conservative than whites elsewhere in the South. As V. O. Key wrote, it is "the whites of the black belts who have the deepest and most immediate concern about the maintenance of white supremacy," and "if the politics of the South revolves around any single theme, it is that of the role of the black belts" (Key 1949, 5-6). Furthermore, the Black Belt has had an enormous influence on national politics. Members of Congress from these areas held influential positions, effectively exercising veto power during the development of the welfare state in the 1920s and 1930s (Katznelson, Geiger, and Kryder 1993). Given these facts, our motivating question is this: Why are whites who currently live in the Black Belt more conservative than whites living elsewhere in the South, particularly on race-related issues? We consider two broad classes of explanations: (i) the historical persistence of attitudes originating in slavery and (ii) contemporary factors, including contemporary demographics and geographic mobility.

\section{Historical persistence of white political attitudes}

Our first hypothesis is that today's Black Belt is more politically conservative than other parts of the South in part because of its history of chattel slavery. We are motivated in this hypothesis by an emerging empirical literature showing that the effects of coercive institutions persist in other 


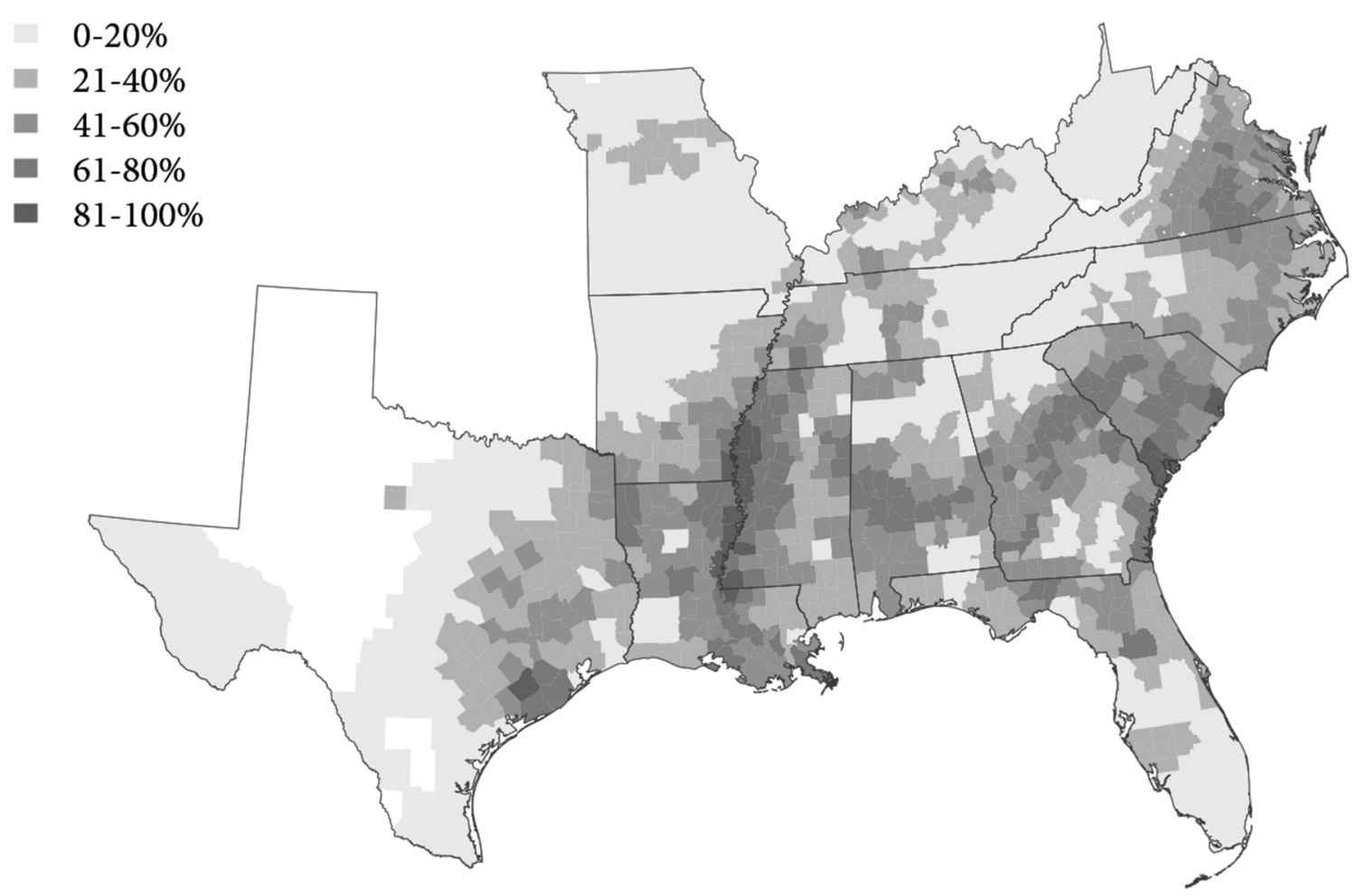

Figure 1. Estimated proportion slave in 1860 by county

contexts. Dell (2010), for example, shows that a colonial forced labor system in Peru and Bolivia led to lower levels of modern-day household consumption and childhood growth. Acemoglu et al. (2012) find that the use of slaves in the colonial gold mines of Colombia predicts modern-day poverty, reduced school enrollment, and decreased vaccination rates. Nunn and Wantchekon (2011) show that Africans whose ancestors were targeted by the slave trade have higher levels of mistrust today than other Africans. Within the United States, O'Connell (2012) demonstrates that areas of the American South that had high numbers of slaves have greater economic inequality between blacks and whites today. Similarly, Lagerlöf (2005) and Nunn (2008) find a negative relationship between the prevalence of slavery and income in the American South, and Mitchener and McLean (2003) find a negative relationship between slavery and modern-day labor productivity. These papers are part of a growing literature that shows that historical institutions such as slavery can affect both institutional and behavioral outcomes long after the institutions themselves disappear (Nunn 2009). This work complements an existing literature documenting the path dependence of historical institutions over time (e.g., Pierson 2000).

Building from this literature, we hypothesize that Southern slavery may have had a similarly lasting effect on political and racial attitudes. The rise and swift fall of chattel slavery together were cataclysmic events. Specifically, the eventual fall of slavery undermined the political and economic power of the Southern whites, particularly in the Black Belt (Du Bois 1935; Foner 2011), making them more hostile toward African Americans and conservative in their political, racial, and economic views (noted contemporaneously by Key 1949). Qualitative accounts (as we document below) suggest that the nature of Southern whites' responses to the collapse of slavery varied according to how locally prevalent - and thus politically and economically important-slavery had been. Areas with more enslaved people reacted more sharply to emancipation by curtailing blacks' rights and oppressing newly freedmen and their mobility.

In addition, a large literature has shown that attitudes can persist historically through both cultural and institutional channels (Nunn and Wantchekon 2011; Voigtländer and Voth 2012). On the one hand, Southern institutions such as Jim Crow helped enforce racial segregation, while racially targeted violence reinforced practices of black subjugation (Woodward [1955] 2002). On the other hand, the culture of the Southern Black Belt was one where black subjugation was passed on within white families and across generations - a process that no doubt included intergenerational socialization (Bisin and Verdier 2000; Boyd and Richerson 1988; Campbell et al. 1980; Jennings and Niemi 1968).

Based on these arguments, we expect that (i) areas that were more reliant on slavery should be more conservative today on race-related issues and in terms of party affiliation, (ii) race-related attitudes should be correlated across generations within the South, and (iii) the effects of slavery 
should be weaker (i.e., should have decayed more) in areas where the incentives for anti-black attitudes faded earlier.

\section{How contemporary demographics could explain regional variation in white political attitudes}

In contrast to the arguments above, much of the political science literature points to contemporary (not historical) forces as providing the explanation for why Black Belt whites are more conservative on race. By and large, the literature has interpreted Key's (1949) work as suggesting that whites contemporaneously become more conservative when they are exposed to the high concentrations of African Americans who live in their communities. ${ }^{1}$ The high concentration of African Americans in today's Black Belt could contemporaneously threaten white dominance, resulting in whites actively choosing more conservative political beliefs today. The literature supporting this idea, known as "racial threat," is voluminous. ${ }^{2}$ For example, Glaser (1994) finds evidence linking negative white attitudes toward civil rights or African American politicians with high concentrations of blacks. Giles and Buckner (1993) find a relationship between black concentrations and white support for racially conservative candidates such as David Duke (these findings are, however, challenged by Voss [1996]). This literature, however, has not considered that slavery could be an independent predictor of contemporary attitudes (apart from its effect on contemporary demographics), making it an omitted variable in studies of racial threat in the South.

Other aspects of the contemporary local context may also affect white attitudes-for example, income gaps between blacks and whites, urban-rural differences, and other contextual and individual-level factors (e.g., Hopkins 2010; Oliver and Mendelberg 2000). ${ }^{3}$ A final category of explanations concerns white mobility through the twentieth century. For example, it could be that more racially conservative whites have migrated into former slaveholding areas, while racial liberals have left, thereby creating a regional pattern in

1. As we note below, Southern slavery is correlated with contemporary black concentration, making it difficult to disentangle the effects of slavery from the effects of contemporary black concentrations.

2. Early studies showed, e.g., that modern black concentrations predict white support for segregationist candidates such as George Wallace (e.g., Wright 1977), racially hostile white attitudes (Blalock 1967; Giles 1977), negative attitudes on school desegregation (Ogburn and Grigg 1956), and higher incidence of lynchings (Reed 1972).

3. Some work has even highlighted the connection between slavery and these contemporary factors (Mitchener and McLean 2003; Nunn 2008; O'Connell 2012). While these papers suggest that slavery might affect contemporary attitudes indirectly through contemporary factors such as economic inequality and prosperity, we find below that slavery has a direct effect on contemporary attitudes that does not work through these channels. political attitudes that is less about persistence of beliefs and more about the sorting of beliefs.

Ultimately much of the public opinion literature focuses on contemporary or individual-level factors in explaining political beliefs rather than on historical forces. Yet Key himself was aware of the importance of history in the context of slavery when he noted that, in the years leading to the Civil War, "those with most at stake - the owners of large numbers of slaves - were to be found roughly in the same areas as present-day black belts" (Key 1949, 6). We now turn to exploring this historical link in terms of regional variation in Southern whites' attitudes.

\section{HISTORICAL SLAVE DATA AND CONTEMPORARY PUBLIC OPINION DATA}

Our main explanatory variable and proxy for slavery's prevalence is the proportion of each county's 1860 population that was enslaved, as measured by the 1860 US Census. Although counts of enslaved people were taken before 1860, we use measures from 1860 because they represent the last record before chattel slavery was abolished in 1865 . In addition, white planters were very mobile in the antebellum period, during which slaves (not land) were their main source of wealth; after emancipation, mobility decreased rapidly as white elites became increasingly oriented toward landowning (Wright 1986, 34). If any local legacy exists, we would expect to see it in data from 1860 . Since county boundaries have shifted since 1860 , we use an area-weighting method to map data from the 1860 Census onto county boundaries in 2000, enabling us to estimate the proportion enslaved in 1860 within modern-day counties. ${ }^{4}$ Figure 1 depicts the data. Overall, we have in our data approximately 4 million enslaved people, constituting $32 \%$ of the Southern population.

\section{Outcome variables measuring contemporary white political and racial attitudes}

We analyze three county-level outcome measures, which come from the Cooperative Congressional Election Study (CCES), a large survey of American adults (Ansolabehere 2010). We pool CCES data from the 2006, 2008, 2009, 2010, and 2011 surveys to create a combined data set of over

4. Total population and total enslaved population in 1860 counties are divided among the counties in 2000 so that the proportion of the 1860 population from 1860 -county $i$ that is assigned to 2000 -county $j$ is based on the size of their overlapping areas. This approach produces estimates and results similar to those provided by (i) O'Connell (2012) $(r=0.986)$, who uses an alternative interpolation technique, and (ii) a simpler method that relies on matching counties by name. See appendix section A for more information on our approach. 
157,000 respondents. We subset these data to the former Confederate states plus Missouri and Kentucky, both of which had significant internal support for the Confederacy, ${ }^{5}$ and to self-identified whites, leaving us with more than 40,000 respondents across 1,329 of the 1,435 Southern counties. In addition, we also investigate individual-level black-white thermometer scores from waves of the American National Election Survey (ANES) from 1984 until 1998, a time period in which the ANES both used a consistent sampling frame and included county-level identifiers for respondents. After restricting the sample to Southern whites, we have an ANES sample of 3,123 individuals across 64 counties in the South. This makes the ANES more restricted in its geographic coverage, but it contains valuable direct questions on the subjective evaluation of racial groups.

The four outcome measures are as follows.

Partisanship. We examine partisanship, because, as many scholars have argued, Southern whites' partisanship (and partisan re-alignment) has been intimately connected to, and reflective of, their attitudes on race and black-white relations (Carmines and Stimson 1989; Key 1949; Kuziemko and Washington 2015; Valentino and Sears 2005). Such partisan identification can not only reflect racial attitudes, as suggested by these papers, but may also reflect beliefs on policy issues closely related to race, including redistribution (Gilens 2009; Lee and Roemer 2006). Partisanship also serves as an important bridge to regional and national politics.

We construct our partisanship measure from a standard seven-point party identification question on the CCES. We operationalize the party variable as whether an individual identified at all with the Democratic Party ( 1 if Democrat; 0 otherwise). ${ }^{6}$ Thus, the county-level measure represents the proportion of whites in each county who identified as Democrats.

Support for affirmative action. All CCES surveys ask respondents whether they support or oppose affirmative action policies, which are described as "programs [that] give preference to racial minorities and to women in employment and college admissions in order to correct for discrimination"

5. The sample thus includes Alabama, Arizona, Arkansas, Florida, Georgia, Kentucky, Louisiana, Mississippi, Missouri, North Caroline, South Carolina, Tennessee, Texas, Virginia, and West Virginia.

6. We use survey data as opposed to voter registration data because primaries in many Southern states are open. Coupled with the dramatic changes in partisanship in the South over the last 40 years, this means voter registration data are unreliable measures of current partisan leanings. Finally, survey data allow us to focus on the partisanship of whites voters only.
(2008 CCES). ${ }^{7}$ We construct the outcome variable by collapsing the four-point scale, from "strongly support" to "strongly oppose," to an indicator representing whether the respondent demonstrated any level of support for affirmative action ( 1 for support; 0 otherwise). At the county level, then, this is the proportion of whites who say that they support affirmative action.

Racial resentment. Kinder and Sears $(1981,416)$ write that racial resentment (or symbolic racism) "represents a form of resistance to change in the racial status quo based on moral feelings that blacks violate such traditional American values as individualism and self-reliance, the work ethic, obedience, and discipline." We construct a third outcome variable using the two CCES questions on racial resentment. The first question, asked in the 2010 and 2011 CCES surveys, asks respondents on a five-point scale whether they agree with the following statement: “The Irish, Italian, Jews and many other minorities overcame prejudice and worked their way up. Blacks should do the same." The second question, asked in 2010, asks respondents, also on a five-point scale, whether they agree that "Generations of slavery and discrimination have created conditions that make it difficult for Blacks to work their way out of the lower class." For the 2010 CCES, when both questions were asked, we rescaled both questions and averaged them to create one measure. The final countylevel measure is the average level of agreement with the racially resentment statement on a five-point scale.

White-black thermometer difference. In many years, the ANES contains "feeling thermometer" questions, which ask respondents to evaluate their feelings about politicians and groups (including racial or ethnic groups) on a scale from 0 to $100 .{ }^{8}$ Since these scales have engendered criticisms that the ratings fluctuate heavily from individual to individual (Wilcox, Sigelman, and Cook 1989) and that they are less stable than party identification (Markus and Converse

7. Although the question wording differs across years, we have no reason to believe that these wording variations affect our analysis.

8. The 1984 ANES gave respondents the following instructions:

I'll read the name of a person and I'd like you to rate the person using the feeling thermometer. Ratings between 50 degrees and 100 degrees mean that you feel favorable and warm toward the person. Ratings between 0 degrees and 50 degrees mean that you don't feel favorable toward the person and that you don't care too much for that person. You would rate the person at the 50 degree mark if you don't feel particularly warm or cold toward that person.

For groups like "blacks" or "whites," the instructions asked "And, still using the thermometer, how would you rate the following?" 
1979), we use them mainly to buttress the findings from our previous three outcome variables. To measure relative racial hostility, we take the difference between white respondents' feeling thermometer ratings toward whites and their feeling thermometer ratings toward blacks. Thus, a positive difference would indicate that respondents have warmer feelings toward whites as opposed to blacks. Only using black thermometer scores yields similar results, but we use the difference in case slavery has an overall effect on racial group thermometer ratings.

Appendix tables A.1 and A.2 report summary statistics for these and other data. Figure 2 depicts the bivariate relationships between proportion slave in 1860 and the four outcome measures from the CCES and ANES. It shows negative, statistically significant relationships between slave prevalence and proportion Democrat and support for affirmative action and positive, statistically significant relationships with racial resentment and thermometer score differences. We now turn to establishing plausible estimates of the causal effect of slavery's prevalence on these outcomes.

\section{SLAVERY'S EFFECTS ON CONTEMPORARY OUTCOMES}

In models that analyze the CCES outcomes, we conduct a county-level analysis using weighted least squares (WLS) with the within-county sample size (appropriately weighted by the sampling weights) as weights. ${ }^{9}$ We opt for analyses at the county level for two reasons. First, the key variable of interest here (in effect, our treatment) is slavery in 1860 , which is only measured at the county level, meaning we cannot detect any within-county variation in this measure. Second, when attempting to estimate the effect of a clusterlevel variable such as this, Green and Vavreck (2008) show that aggregating units up to the cluster level provides the most accurate variance estimates. While it is sometimes useful to trade off this accuracy on standard error estimation to allow for the inclusion of individual-level covariates, in our context many individual-level covariates are potentially directly affected by the treatment (slavery), so including them may introduce posttreatment bias (Rosenbaum 1984). In spite of this, we present respondent-level analyses in appendix table A.3 that include additional respondent-level controls and standard errors clustered at the county level. These results are consistent with our county-level results below, although we caution that the estimates may be biased. Fur-

9. Whites in high-black areas are less likely to be sampled than whites in low-black areas, since the sampling reflects the population distribution of whites. If we were making inferences about both blacks and whites, this approach would be problematic. However, we use the white population subset to make inferences only about the Southern white population. thermore, we opt for an individual-level analysis for our results on NES thermometer scores since we are collecting together 15 years' worth of survey results wherein racial attitudes have changed dramatically, making it important to include survey-year fixed effects in our models. The level of analysis has very little impact on the substantive results, and the ANES results at the county level are presented in appendix table A.11.

In table 1, we report the baseline estimates of slavery's effect on the three CCES outcomes. Column 1 of table 1 presents the simple WLS relationship between slavery and white partisan identification, which measures the relationship depicted in figure 2 . In the remaining columns, we include state-level fixed effects to address the possibility that states adopted different policies that could have influenced slave shares in 1860 and could affect our outcome variables in ways unrelated to slavery. In addition, in the remaining columns, we control for factors that may have been predictive of proportion slave in 1860 . These "1860 covariates," unless otherwise noted, come from the 1860 US Census and address possible differences between slaveholding and nonslaveholding counties. First, since wealthier or more populous counties may have had more or fewer slaves, we control for economic and demographic indicators from 1860. These include (i) the log of the total county population, (ii) the proportion of farms in the county smaller than 50 acres, (iii) the inequality of farmland holdings as measured by the Gini coefficient for landownership (Nunn 2008), (iv) the log of total farm value per improved acre of farmland in the county, and (v) the log of the acres of improved farmland. Second, because counties may have had different norms about race, we include controls for (vi) the proportion of total population in 1860 that is free black. We also control for characteristics related to trade and commerce, including separate indicators for whether the county had access to (vii) rails and (viii) steamboat-navigable rivers or canals. Finally, to account for any remaining spatial variation, we control for (ix) the log of the county acreage, $(\mathrm{x})$ the ruggedness of the county terrain (Hornbeck and Naidu 2014), and (xi) the latitude and longitude of the county, as well as their squared terms (to flexibly control for spatial variation in the outcome). For all of these variables, we mapped 1860 data onto modern county boundaries using the procedure described in appendix section A. ${ }^{10}$

10. In other results, we have additionally controlled for antebellum county-level vote share for the Democrats in various presidential elections. These controls do not affect the results but have the unfortunate byproduct of dropping South Carolina, which decided its electoral votes by the state legislature. For that reason, we do not include this particular control here. 


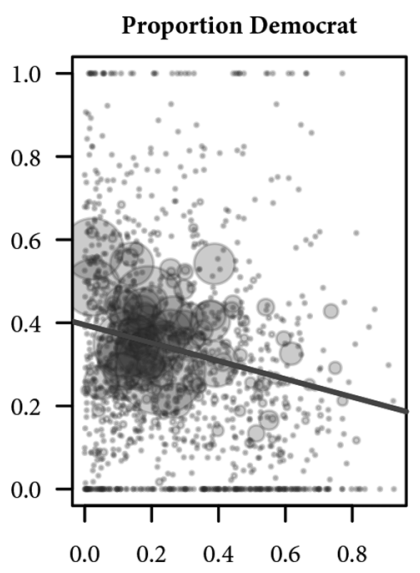

Proportion Slave, 1860

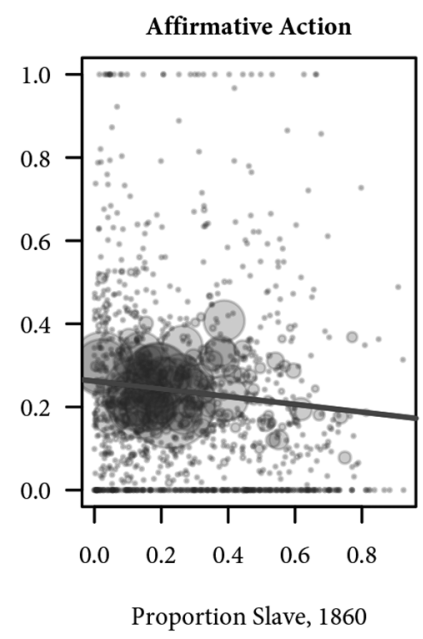

Proportion Slave, 1860
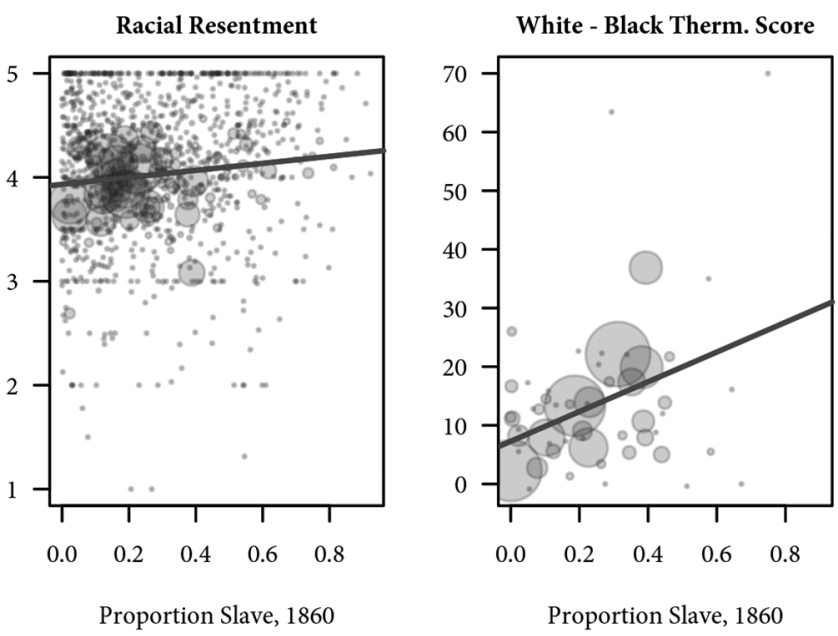

Figure 2. Bivariate relationships between proportion slave in 1860 and the four outcome measures with a linear fit. All four relationships are significant at $p<.05$ significance levels. Size of the points are in proportion to their within-county sample size (weighted by sampling weights).

As columns 2-4 show, the conditional effects of slavery are meaningful and significant for all three CCES outcome variables. To illustrate, a 20 percentage point increase in the slave proportion (roughly a one standard deviation change) is associated with a 2.3 percentage point decrease in the share of whites who currently identify as Democrats (and so roughly a 4.6 percentage point shift toward the Republican Party), a 3 percentage point decrease among those who currently support affirmative action, a 0.08 point increase in the average racial resentment score in the county, and a 7 point increase in the county average thermometer preference for whites relative to blacks. These represent approximately a 0.09-0.13 standard deviation change in the CCES outcomes and roughly a 0.32 standard deviation change in the thermometer score difference. The individual-level results for the CCES in appendix table A.3 give very similar estimates, making it unlikely that these results are due to some sort of ecological or aggregation bias. ${ }^{11}$ Finally, we present results for each racial thermometer score separately in appendix table A.10 and the full set of county-level results for thermometer scores in appendix table A.11, both of which are consistent with results in table 1.

\section{Instrumenting for slavery with cotton suitability}

There are two potential concerns with the above as a causal analysis. First, the 1860 slave data are historical and may be measured with error. Second, we may have inadequately controlled for all pre-1860 covariates that simultaneously

11. In appendix table A.4, we present results with a full set of interactions between slavery and individual-level covariates, and we find no significant interactions with education, household income, religiosity, gender, or age. In the same table, we show that there are no consistent interactions with contemporary contextual variables as well. affect slave proportion in 1860 and political attitudes today, which might result in a spurious relationship. To allay some of these concerns, we present additional robustness checks, matching analyses, and counterfactual comparisons between the North and the South in the appendix. Here, we present results from an alternative specification that instruments for slave proportion in 1860 with county-level measures of the environmental suitability for growing cotton. We constructed these measures using data from the UN Food and Agriculture Organization (FAO). ${ }^{12}$ Table 2 presents our instrumental variable (IV) estimates of the effects of proportion slave on the four outcome measures using a two-stage least squares (2SLS) model with state fixed effects, log of the county size, ruggedness of the terrain, water access, latitude and longitude, and their squared terms included as controls in both stages. ${ }^{13}$ Column 1 presents the first-stage relationship between cotton suitability and proportion slave. Columns 2-5 present the second-stage estimates of the effect of proportion slave on the outcome measures.

12. These measures represent the maximum potential cotton yield based on soil, climate, and growing conditions. The estimates are based on climate averages from 1961 to 1990, and we average the "intermediate" and "high" levels of inputs, which refer to the effort required to extract the resource. We omit suitability for other crops, such as tobacco, because they have no relationship with slavery conditional on cotton suitability. While these measures use data from the contemporary period, we expect most of the changes to the suitability between 1860 and 1960 to either be uniform shifts across the entire region due to worldwide climate change or be unrelated to local political attitudes.

13. To strengthen the internal validity of our design and minimize the potential for confounding, we omit counties with zero cotton suitability from the analyses. We use county-level data for the ANES measures to side-step the issue of clustering by county in the 2SLS model. 
Table 1. Effects of Slavery on White Political Attitudes

\begin{tabular}{|c|c|c|c|c|c|}
\hline & \multicolumn{2}{|c|}{ Proportion Democrat } & \multirow{2}{*}{$\begin{array}{c}\text { Support for } \\
\text { Affirmative Action } \\
\text { (3) }\end{array}$} & \multirow{2}{*}{$\frac{\begin{array}{c}\text { Racial } \\
\text { Resentment }\end{array}}{(4)}$} & \multirow{2}{*}{$\begin{array}{c}\text { White-Black } \\
\text { Thermometer Difference } \\
\text { (5) }\end{array}$} \\
\hline & (1) & (2) & & & \\
\hline Proproportion slave, 1860 & $\begin{array}{c}-.217^{\star *} \\
(.023)\end{array}$ & $\begin{array}{c}-.127^{* *} \\
(.043)\end{array}$ & $\begin{array}{c}-.145^{\star *} \\
(.036)\end{array}$ & $\begin{array}{l}.463^{* *} \\
(.139)\end{array}$ & $\begin{array}{l}36.125^{\star *} \\
(9.211)\end{array}$ \\
\hline $\begin{array}{l}\text { Level } \\
1860 \text { covariates }\end{array}$ & County & $\begin{array}{l}\text { County } \\
\sqrt{ }\end{array}$ & $\begin{array}{l}\text { County } \\
\sqrt{ }\end{array}$ & $\begin{array}{l}\text { County } \\
\sqrt{ }\end{array}$ & Individual \\
\hline State fixed effects & & $\sqrt{ }$ & $\sqrt{ }$ & $\sqrt{ }$ & $\sqrt{ }$ \\
\hline State-year fixed effects & & & & & $\sqrt{ }$ \\
\hline Clustered SEs & & & & & $\sqrt{ }$ \\
\hline$N$ & 1,242 & 1,152 & 1,152 & 1,027 & 1,489 \\
\hline$R^{2}$ & .065 & .203 & .101 & .143 & .183 \\
\hline
\end{tabular}

Note. Models 1-4 are weighted least squares at the county level, with within-county sample sizes, adjusted by sampling weights, as weights. Model 5 is weighted least squares at the individual level with state-year fixed effects. Standard errors, in parentheses, are clustered at the county level in model 5 . There are 50 counties in model 5 .

** $p<.01$.

The results show second-stage estimates that are stronger than our baseline estimates, reported in table 1.

For the IV approach to serve as a plausible identification strategy, cotton suitability must have an effect on contemporary attitudes exclusively through slavery, a strong assumption. Cotton suitability could, for example, determine how rural a county is today, which in turn could affect political attitudes. While the exclusion restriction is an untestable assumption, we assess its plausibility using a falsification test motivated by Nunn and Wantchekon (2011). We first estimate the reduced-form relationship between cotton suitability and contemporary beliefs both within and outside of the South - that is, mostly in the North. The legal absence of slavery in the North in this time period means that cotton suitability cannot affect political attitudes through slave prevalence. Any relationship between cotton suitability and political attitudes in the North would be a direct effect of cotton suitability on political attitudes. In appendix section B.2, we present results from this analysis showing that, outside the South, the relationship between cotton suitability and political attitudes is either very small or in the opposite direction as in the South. This lends some additional credibility to our IV approach.

\section{EXPLANATIONS FOR SLAVERY'S EFFECT ON CONTEMPORARY WHITE ATTITUDES BASED ON EXISTING THEORIES OF POLITICAL BEHAVIOR}

We now turn to explaining the above findings. We first consider three possible explanations rooted in contemporary factors, as opposed to historical ones: racial threat, geographic sorting, and contemporary income inequality between blacks and whites, which could lead to statistical discrimination. (We examine two other explanations-rural/urban differences and the effects of Civil War destruction - in the appendix.) After finding no support for these contemporary factors, we turn in the following section to what we believe is the more likely explanation concerning the long-term historical persistence of political attitudes.

\section{Racial threat (contemporary black concentrations)}

As noted above, one plausible explanation for our results is that they are driven by contemporary black concentrations, which correlate highly with slavery. Indeed, the correlation between percent slave in 1860 and percent black in 2000 is 0.77 . Since the local prevalence of slavery has produced high concentrations of blacks in the modern-day Black Belt, whites living in the Black Belt could be more conservative today simply due to modern racial threat.

To assess whether modern racial threat accounts for our findings, we check how much of our baseline results can be explained by contemporary black concentrations. We do so in two ways. First, we include the "mediator" (here, proportion black in 2000 as measured by the 2000 US Census) as a covariate in the baseline specification, along with the treatment of interest (proportion slave in 1860). This analysis is shown in table 3, columns 1,3, and 5. The coefficient on proportion slave in 1860 remains significant and actually strengthens, suggesting that its direct effect does not operate through proportion black in 2000. 
Table 2. Instrumental Variables Estimates of the Effect of Slavery

\begin{tabular}{|c|c|c|c|c|c|}
\hline & $\begin{array}{l}\text { Proportion } \\
\text { Slave, } 1860 \\
\quad(1)\end{array}$ & $\begin{array}{l}\text { Proportion } \\
\text { Democrat } \\
\quad(2)\end{array}$ & $\begin{array}{c}\text { Support for } \\
\text { Affirmative Action } \\
\text { (3) }\end{array}$ & $\begin{array}{l}\text { Racial } \\
\text { Resentment } \\
\quad(4)\end{array}$ & $\begin{array}{l}\text { White-Black } \\
\text { Thermometer Difference } \\
\text { (5) }\end{array}$ \\
\hline Cotton suitability & $\begin{array}{l}.441^{\star *} \\
(.037)\end{array}$ & & & & \\
\hline Proportion slave, 1860 & & $\begin{array}{c}-.277^{\star \star} \\
(.104)\end{array}$ & $\begin{array}{l}-.247^{\star *} \\
(.088)\end{array}$ & $\begin{array}{l}.823^{*} \\
(.352)\end{array}$ & $\begin{array}{r}51.748^{\star} \\
(19.305)\end{array}$ \\
\hline $\begin{array}{l}\text { State fixed effects } \\
\text { Geographic controls }\end{array}$ & $\begin{array}{l}\sqrt{ } \\
\sqrt{ }\end{array}$ & $\begin{array}{l}\sqrt{ } \\
\sqrt{ }\end{array}$ & $\sqrt{ }$ & $\begin{array}{l}\sqrt{ } \\
\sqrt{ }\end{array}$ & $\begin{array}{l}\sqrt{ } \\
\sqrt{ }\end{array}$ \\
\hline Model & $\begin{array}{c}\text { 2SLS } \\
\text { First stage }\end{array}$ & $\begin{array}{c}\text { 2SLS } \\
\text { Second stage }\end{array}$ & $\begin{array}{c}\text { 2SLS } \\
\text { Second stage }\end{array}$ & $\begin{array}{c}\text { 2SLS } \\
\text { Second stage }\end{array}$ & $\begin{array}{c}\text { 2SLS } \\
\text { Second stage }\end{array}$ \\
\hline $\begin{array}{l}N \\
F \text {-statistic }\end{array}$ & $\begin{array}{c}1,120 \\
80.077^{\star *}(\mathrm{df}=21 ; 1,098)\end{array}$ & 1,120 & 1,120 & 998 & 51 \\
\hline
\end{tabular}

Note. Model 1 is the first-stage relationship. Models $2-5$ are weighted two-stage least-squares models, with weights as given in table 1 . Standard errors are in parentheses.

${ }^{*} p<.05$.

${ }^{* *} p<.01$.

These estimates, however, could suffer from posttreatment bias (Rosenbaum 1984). After all, the modern geographic distribution of blacks is a direct consequence of the prevalence of slavery (as noted by Key [1949]). In addition, including the proportion black today as a mediator in a mediation approach would violate the key assumption of no intermediate confounders (Imai et al. 2011). We address these twin concerns by using a method developed in biostatistics by Vansteelandt (2009) and applied to other social science contexts by Acharya et al. (forthcoming). This method enables us to calculate the controlled direct effect of slavery, which is the effect of slavery on our outcomes if we were to fix the modern-day concentration of African Americans at a particular level (see Acharya et al. [forthcoming] for a technical overview of the methodology). To implement the method, we use a two-stage estimator, called the sequential g-estimator, that estimates a controlled direct effect of slavery when we have a set of covariates that satisfies the assumption that there exist no omitted variables for two relationships: one between the outcome and

Table 3. Effects of Slavery on White Attitudes Net the Effect of the Contemporary Proportions of African Americans

\begin{tabular}{|c|c|c|c|c|c|c|}
\hline & \multicolumn{2}{|c|}{ Proportion Democrat } & \multicolumn{2}{|c|}{ Affirmative Action } & \multicolumn{2}{|c|}{ Racial Resentment } \\
\hline & (1) & (2) & (3) & (4) & $(5)$ & (6) \\
\hline Proportion slave, direct effect & $\begin{array}{c}-.150^{\star *} \\
(.043)\end{array}$ & $\begin{array}{r}-.130^{*} \\
(.057)\end{array}$ & $\begin{array}{c}-.153^{\star *} \\
(.037)\end{array}$ & $\begin{array}{c}-.130^{* *} \\
(.042)\end{array}$ & $\begin{array}{l}.514^{\star *} \\
(.140)\end{array}$ & $\begin{array}{l}.472^{*} \\
(.184)\end{array}$ \\
\hline Proportion black, 2000 & $\begin{array}{l}.172^{\star *} \\
(.043)\end{array}$ & & $\begin{array}{c}.062 \\
(.037)\end{array}$ & & $\begin{array}{c}-.416^{\star *} \\
(.140)\end{array}$ & \\
\hline State fixed effects & $\sqrt{ }$ & $\sqrt{ }$ & $\sqrt{ }$ & $\sqrt{ }$ & $\sqrt{ }$ & $\sqrt{ }$ \\
\hline 1860 covariates & $\sqrt{ }$ & $\sqrt{ }$ & $\sqrt{ }$ & $\sqrt{ }$ & $\sqrt{ }$ & $\sqrt{ }$ \\
\hline Bootstrapped SEs & & $\sqrt{ }$ & & $\sqrt{ }$ & & $\sqrt{ }$ \\
\hline Model & WLS & Seq. g-est. & WLS & Seq. g-est. & WLS & Seq. g-est. \\
\hline$N$ & 1,152 & 1,152 & 1,152 & 1,152 & 1,027 & 1,027 \\
\hline$R^{2}$ & .214 & .209 & .103 & .095 & .151 & .144 \\
\hline
\end{tabular}

Note. Columns 1, 3, and 5 simply include proportion black in the year 2000 as an additional control to the baseline specification from table 1 . Columns 2 , 4, and 6 use sequential g-estimation (Seq, g-est) of Vansteelandt (2009). WLS = weighted least squares. Standard errors are in parentheses.

${ }^{*} p<.05$.

${ }^{* *} p<.01$. 
proportion slave in 1860 and the other between the outcome and proportion black in 2000 (Acharya et al., forthcoming; Vansteelandt 2009). ${ }^{14}$ To estimate the direct effect of slavery, we first estimate the effect of contemporary black concentrations on whites' views today, controlling for all of our 1860s covariates and including the additional intermediate covariates in footnote $15 .{ }^{15}$ We then transform each of the outcome variables by subtracting the effect of black concentrations to create counterfactual estimates of the outcomes as if all counties had the same proportion black today. ${ }^{16} \mathrm{Fi}$ nally, we estimate the effect of proportion slave on this transformed variable, which gives us the controlled direct effect of proportion slave on our measures of contemporary political attitudes.

Estimates from this analysis are reported in columns 2, 4 , and 6 of table $3 .{ }^{17}$ Compared to the baseline estimates of table 1 and the potentially biased estimates in columns 1, 3, and 5 , these results demonstrate that contemporary black shares have little influence on slavery's effect on any of the outcomes. The direct effects of slave proportion are similar to those in table 1 and are still highly significant. Moreover, once we account for slavery in 1860, contemporary black concentrations appear to have the opposite effect that racial threat theory would predict for Southern white attitudes. Finally, with the full controls from the first stage of the sequential g-estimator, the effect of proportion black today is no longer significant (appendix table A.12). Thus, we see no evidence that slavery's effects operate via contemporary black concentrations.

\section{Geographic sorting}

The next possibility is that population sorting explains our results. For example, racially hostile whites from other parts of the South (or elsewhere) may have migrated to former slave counties during the last 150 years. Analogously, whites

14. That is, we want to control for intermediate factors that possibly led from slavery in 1860 to black concentrations today (and that are correlated with white attitudes today). To determine this set of covariates, we draw on the racial threat literature (see, e.g., Giles and Buckner 1993) and include log population in 2000, unemployment in 2000, percent of individuals with high school degrees in 1990, and log median income in 2000. These results assume no interaction between proportion slave and contemporary proportion black, but weakening this assumption does not change the findings (Acharya, forthcoming).

15. Results from this first stage can be found in appendix table A.12.

16. That is, we take the coefficient on proportion black, multiply that by the actual share black in the county, and then subtract this product from each of the three white attitudinal outcome variables.

17. To account for the added uncertainty of the two-step nature of sequential g-estimation, we report bootstrapped standard errors. who hold more racially tolerant beliefs may have continually left former slaveholding areas.

For geographic sorting to explain our results, patterns of mobility into (and out of) the former slaveholding areas would have to differ from non-slaveholding areas. To investigate this possibility, we look into patterns of migration in a five-year snapshot from 1935-1940, drawing on the public use microsample (PUMS) of the 1940 US Census (Ruggles et al. 2010). This year of the census is unique in that it provides the county in which a person resided in 1935 and in 1939. These data allow us to investigate if white migrants into or out of former slave areas during this time period were somehow distinct from other white migrants. If sorting plays an important role in our results, we would expect to see differences between migrants to/from highslave areas versus low-slave areas. To test for differences among out-migrants, we adopted the following strategy: we ran a regression of individual characteristics on outmigration status for white respondents, the proportion of slaves in the respondent's 1935 county of residence, and the interaction between the two. We also included the 1860 covariates and state fixed effects for the 1935 counties. The interaction in this regression measures the degree to which differences between out-migrants and those who didn't migrate varies as a function of proportion slave. For inmigration, we take a similar approach but replace the characteristics of the 1935 county of residence with the characteristics of the 1939 county of residence.

Figure 3 depicts the results from this analysis and shows the differences between white migrants and nonmigrants across a number of characteristics. ${ }^{18}$ The figure depicts how these effects vary by proportion slave. For continuous outcomes, the effects are in terms of standard deviations; for binary outcomes, they are in terms of differences in proportions. With age, for example, this figure shows that both out-migrants and in-migrants are significantly younger compared to those who remained in their counties. However, the key point is that this pattern is the same for lowslave and high-slave counties, as evidenced by the overlapping estimates. Thus, migrants into or out of high-slave counties are not any younger than migrants from or to other counties. This pattern holds more generally: migrants in the 1935-40 period are distinct from nonmigrants, but those differences are fairly constant across proportion slave in the county. Indeed, across all of these characteristics, there are no significant interactions between migrant status and proportion slave, meaning that migrants from/to high-

18. See the IPUMS documentation at https://usa.ipums.org/ for a complete description of these census measures. 

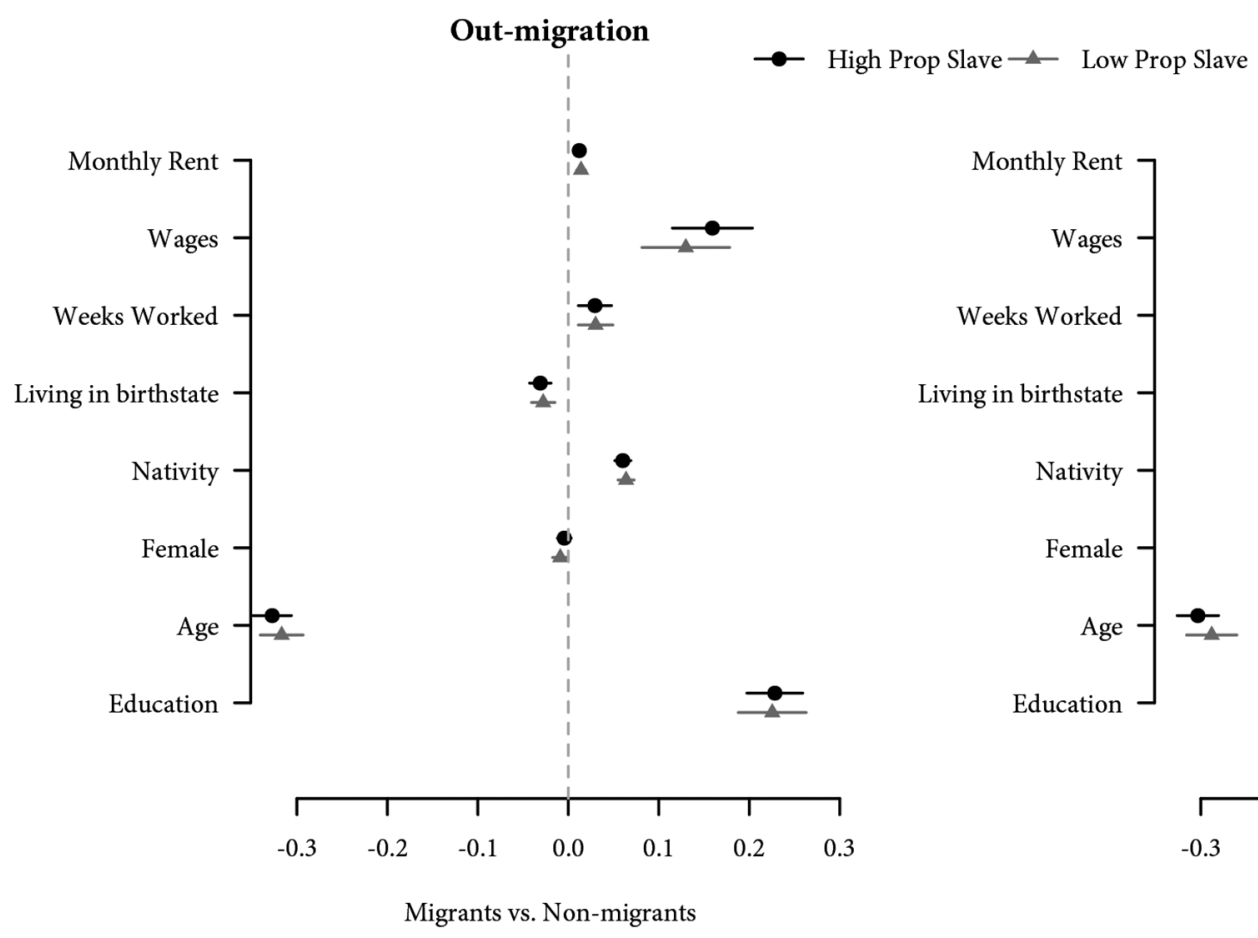

In-migration

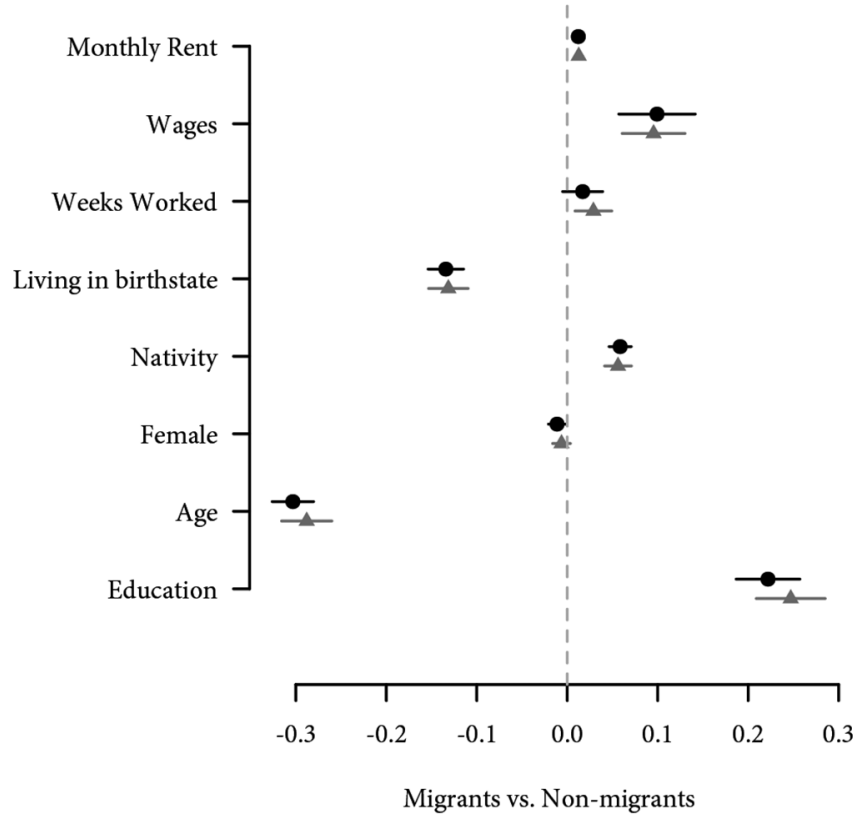

Figure 3. Characteristics of white out-migrants and in-migrants compared to white nonmigrants for high-slave and low-slave counties, where migration took place between 1935 and 1939. In the left panel, each point is the estimated difference between nonmigrants and out-migrants from high-slave areas (dots) and between nonmigrants and out-migrants from low-slave areas (triangles), conditional on 1860 covariates of the individual's 1935 county of residence. The right panel is the same for in-migration, conditional on 1860 covariates of the individual's 1939 county of residence.

slave and low-slave areas appear very similar to each other. These results are specific to a specific five-year period in American history for which we have data, but they do provide suggestive evidence that the differences we are seeing are not due to geographic sorting alone.

In addition, we also provide additional evidence in appendix $\mathrm{D}$, in which we analyze contemporary mobility data from the 2000 US Census. These analyses show mobility mostly from formerly low-slave to low-slave areas or from formerly high-slave to high-slave areas (as opposed to mobility between former low-slave and former high-slave areas, or vice versa). Taken together, the evidence suggests that geographic sorting is unlikely to be the exclusive explanation behind our results.

\section{Inequality and statistical discrimination}

The final alternative explanation that we consider here is that our regional patterns are the outcome of the contemporary economic landscape - in particular, contemporary economic inequality between blacks and whites. O'Connell (2012), for example, finds that slavery in 1860 predicts black-white income inequality today (results echoed by Lagerlöf [2005] and Nunn [2008]). Her results suggest that our findings might be explained by a theory of statistical discrimination (Becker 2010). In addition, because poverty correlates with other traits (e.g., higher instances of crime) then we might expect this type of statistical discrimination to be even more pronounced. Consistent with O'Connell (2012), we show in appendix table A.14 that slavery has an effect on black-white income inequality measured using both 1940 wages and 2014 median incomes, though the effects have attenuated substantially since 1940 . Could this income inequality between blacks and whites in the Southern Black Belt be driving our findings on whites' political attitudes, for example, through statistical discrimination (discrimination against blacks because they are, on average, poorer than whites)?

We address this question with two analyses, both of which cast doubt that income inequality and statistical discrimination explain our results. First, we show that local income inequality is a weak predictor of our main outcome variables, and, if anything, the effects are in the opposite direction as statistical discrimination theory would predict. These are shown in table 4, which shows that inequality in 2014 is weakly related to political outcomes, and when it is related, the relationships are in the opposite direction of what would explain our results. In other words, counties with higher black-white inequality are places where whites are more likely to be Democrats, more likely to support affirmative action, and are about as racially resentful as 
Table 4. Effect of Slavery versus the Effect of Inequality

\begin{tabular}{|c|c|c|c|c|c|c|}
\hline & \multicolumn{2}{|c|}{ Proportion Democrat } & \multicolumn{2}{|c|}{ Support for Affirmative Action } & \multicolumn{2}{|c|}{ Racial Resentment } \\
\hline & $(1)$ & (2) & (3) & $(4)$ & (5) & (6) \\
\hline Log white-black income ratio, 2014 & $\begin{array}{c}.040^{*} \\
(.017)\end{array}$ & $\begin{array}{l}.055^{\star *} \\
(.019)\end{array}$ & $\begin{array}{c}.027^{+} \\
(.015)\end{array}$ & $\begin{array}{l}.041^{\star} \\
(.016)\end{array}$ & $\begin{array}{c}-.088 \\
(.057)\end{array}$ & $\begin{array}{r}-.088 \\
(.063)\end{array}$ \\
\hline Proportion slave, 1860 & & $\begin{array}{c}-.135^{\star *} \\
(.044)\end{array}$ & & $\begin{array}{c}-.158^{\star *} \\
(.037)\end{array}$ & & $\begin{array}{l}.541^{* *} \\
(.144)\end{array}$ \\
\hline State fixed effects & $\sqrt{ }$ & $\sqrt{ }$ & $\sqrt{ }$ & $\sqrt{ }$ & $\sqrt{ }$ & $\sqrt{ }$ \\
\hline 1860 covariates & $\sqrt{ }$ & $\sqrt{ }$ & $\sqrt{ }$ & $\sqrt{ }$ & $\sqrt{ }$ & $\sqrt{ }$ \\
\hline$N$ & 1,140 & 994 & 1,140 & 994 & 1,017 & 894 \\
\hline$R^{2}$ & .180 & .226 & .075 & .124 & .069 & .159 \\
\hline
\end{tabular}

Note. Inequality here is measured by the $\log$ of the ratio of white to black median incomes within counties in 2014 . Data come from the American Community Survey, 2009-14.

$+p<.10$.

${ }^{*} p<.05$.

${ }^{* *} p<.01$.

whites elsewhere. Furthermore, the table also shows that including contemporary black-white income inequality as a covariate in our baseline specification does not substantially change our estimates. ${ }^{19}$

Second, we check an observable implication of the inequality account. If income inequality drives slavery's effects, then we would expect the marginal effect of slavery on attitudes to vary in the income level of the respondent. For example, higher-income respondents might be more (or less) discriminatory on the basis of black-white income inequality. In appendix table A.15, we show that there is no interaction between respondent income and proportion slave. Taken together, these analyses provide evidence against income inequality and economic conditions being the main mechanism behind our findings.

\section{AN EXPLANATION FOR SLAVERY'S EFFECT ON CONTEMPORARY WHITE ATTITUDES BASED ON THE HISTORICAL PERSISTENCE OF POLITICAL ATTITUDES}

If the above explanations, largely rooted in contemporary factors or population sorting, do not explain our findings, then what does? In this section, we lay out the theory of historical persistence in political attitudes. In our context, this is the idea that slavery and its collapse reinforced regional differences in political attitudes and these differences have persisted over time.

The prevalence of slavery, coupled with the shock of its removal, created strong incentives for Black Belt whites to

19. The coefficients on proportion slave in these models, however, should be interpreted with caution due to the potential for post-treatment bias. try to preserve both their political and economic power by promoting racially targeted violence, anti-black norms, and, to the extent legally possible, racist institutions. These reinforced racial and political beliefs about black subjugation within the Southern Black Belts, which, via institutional path dependence and intergenerational socialization, have persisted to the present day. While there is no question that anti-black attitudes were rampant throughout the South before the Civil War, we show in this section that even for counties that were politically similar before the war, differences in partisan voting became more pronounced in the late nineteenth and early twentieth centuries. Thus, although racism was prevalent across the high-slave and lowslave South in the antebellum period, these areas diverge greatly in terms of both institutionalized and socially enforced racism around the time of the Civil War, specifically the period of Redemption that followed Reconstruction (Foner 2011; Logan 1954). ${ }^{20}$

Below, we draw on work in both history and economics to provide some qualitative background to the way in which Southern white elites had incentives to foster and sustain anti-black suppression in the former bastions of slavery. We then provide evidence for our mechanism by presenting evidence on (i) the burgeoning political importance of race in the postbellum period, (ii) postbellum racial vi-

20. The more general idea behind this theory is that when an entrenched social and economic institution like slavery is abruptly and forcibly abolished, previously powerful groups (ex-slaveowning white elite) seek to establish other local and informal institutions that serve a similar purpose to that of the previous, forcibly abolished formal institution (slavery) (e.g., Acemoglu et al. 2011). 
olence (including lynchings) and economic oppression, (iii) the weakening of economic incentives for racial hostility that took place as a result of the movement toward agricultural mechanization beginning in the 1930s, and (iv) evidence for intergenerational transmission of racial attitudes.

\section{Political and economic incentives for black repression in the postbellum years}

Why would racial attitudes in the Black Belt persist after the Civil War, even as other regions of the country gradually changed their views on race? Our explanation for this postbellum divergence lies in the fact that, after emancipation, Black Belt white elites faced two interrelated threats. The first was political. In areas where blacks outnumbered whites (in some cases 9 to 1 ), the abrupt enfranchisement of blacks threatened white control over local politics (Du Bois 1935; Key 1949; Kousser 1974). This gave whites in former slaveholding counties an incentive to promote an environment of violence and intimidation against the new freedmen, with the purpose of election fraud and disenfrachisement (Du Bois 1935; Kousser 1974). The second threat to white elites was economic. The emancipation of slaves after the Civil War was a major shock to the Southern economy: blacks now had to be paid wages (Higgs 1977). Furthermore, emancipation brought blacks some freedom over the amount of labor they supplied, and many ex-slaves chose to work for themselves rather than for the white ruling class (Ransom and Sutch 2001). This both reduced the labor supply and increased labor costs sharply, threatening the Southern plantation economy (Alston and Ferrie 1993; Ransom and Sutch 2001). ${ }^{21}$ Whites therefore had an incentive to establish not just new forms of labor coercion that could replace slavery but also new political restrictions that would help protect white hegemony.

Since black populations and large-scale agricultural production were greatest in former slaveholding counties, it was in these counties that Southern elites exerted greater efforts toward repression (Kousser 1974). These repressive techniques are well documented in the economics and history literatures (Alston and Ferrie 1993; Blackmon 2008; Lichtenstein 1996; Wiener 1978). For example, Wiener (1978, 62) describes how "planters used [Ku Klux] Klan terror to keep blacks from leaving the plantation regions, to get them to work, and keep them at work, in the cotton field." Also

21. Some of these concerns were mitigated by the sharecropping system that became pervasive in the postbellum period. This aligned the incentives of the planters and the laborers to some extent (Ransom and Sutch 2001, 88-89), but these arrangements did not reduce the incentives of planters to further bolster their position in the labor market. well documented is the fact that poor whites were complicit with the landowning elite and would engage in and support violent acts toward blacks, even though such violence could presumably also lower white wages (Blackmon 2008; Du Bois 1935; Roithmayr 2010). Note that these forces are distinct from the modern interpretation of racial threat, under which whites would find high concentrations of black populations undesirable. In our explanation, the Southern white population sought to control, police, and dominate black labor resources. Blacks were not threatening because of their presence (as racial threat would imply); they were threatening because they were an important provider of labor and, in the post-emancipation environment, they could leave.

Three additional factors sustained and nurtured antiblack attitudes in the former slaveholding counties, both within the community and over time. The first is the continued and perhaps increased use of social norms that directly or indirectly put blacks in an inferior position relative to whites (Du Bois 1935; Logan 1954). ${ }^{22}$ The second is the expansion of these attitudes across local white communities, which could operate in a manner consistent with existing theories of the diffusion of political opinions from elites to the general public (Zaller 1992). The last is the intergenerational transfer of political and racial attitudes, in a manner consistent with theories of intergenerational socialization both in economics and cultural anthropology (Bisin and Verdier 2000; Boyd and Richerson 1988) as well as in political science (Campbell et al. 1980; Jennings and Niemi 1968). ${ }^{23}$ In our context, attitudes could be passed down from one generation to the next through both cultural and institutional channels, for example, via institutions such as Jim Crow or socially enforced segregation and racially motivated violence. In line with the literature, such transmission would necessarily be imperfect, suggesting that there is some decay in these geographically based relationships over time. This leads to one important empirical prediction: the effects of slavery should be smaller in

22. The political and economic incentives for racial violence and oppression is likely to have produced or reinforced racially hostile attitudes among whites through psychological and other channels. For example, whites might have developed or maintained racially hostile attitudes to minimize the "cognitive dissonance" associated with racially targeted violence toward blacks (Acharya, Blackwell, and Sen 2015). Theories in social psychology, beginning with the work of Festinger (1957), would suggest that engaging in violence could produce, or sustain, hostile attitudes among members of the perpetrating group toward the victim group, if individuals from the perpetrating group seek to minimize such dissonance.

23. We note that under our mechanism, it is sociopolitical attitudes, rather than partisanship, that are passed down from parent to children. This makes our mechanism consistent with the partisan realignment that took place in the 1960s, given the assumption that partisanship depends at least in some part on attitudes. 
areas where the incentives for anti-black attitudes faded earlier. Below, we provide evidence for this prediction.

Although our discussion focuses on the postbellum South, our argument is not that racial hostility was nonexistent before the Civil War. Instead, the incentives that gained strength at the time of emancipation likely exacerbated the political differences between former slaveholding and non-slaveholding areas. Racially hostile attitudes, in other words, may have dissipated more quickly in areas that were non-slaveholding and were less reliant on the provision of inexpensive black labor. The South was surely racist before the Civil War, but for this to explain our results, the strength of the racism would have to align with the density of slavery. Our previous analyses provide some limited evidence against this idea: in results presented above, for example, our effects are robust to controlling for the antebellum presence of freed blacks in the county, which may be a possible indicator of antebellum racial attitudes. They are also robust to the inclusion of a host of antebellum factors capturing economic and political differences. Below, we focus more closely on these ideas.

\section{Timing of the political divergence and the importance of the Reconstruction Period}

What additional evidence do we have that racial attitudes became politically salient in the postbellum period? To shed light on this question, we examine the relationship between proportion slave in 1860 and a long-standing historical measure of political attitudes, presidential vote shares. Until realignment in the middle of the twentieth century, the Democratic Party was the racially conservative party, while the Republican Party was the racially progressive party (Black and Black 1987). In the period before the Civil War, the Second Party system of Democrats and Whigs attempted to remove slavery as a national issue, but slaveholding still drove political differences on issues such as internal improvements and tariffs, with elite slaveholders more likely to support Whig candidates (Holt 1999, 115-21). Do these differences drive the relationship between slavery and modern attitudes? Or do post-Civil War events drive the results we see above?

We address these questions by examining the effect of slavery on county-level Democratic vote share of the presidential vote between 1844 and $1968 .{ }^{24}$ To analyze the time

\footnotetext{
24. Since election outcomes are not disaggregated by voter race, these data also include black voters. Blacks voted in large numbers following emancipation but were systematically disenfranchised between in the late nineteenth and early twentieth centuries. Large-scale re-enfranchisement did not occur until the Voting Rights Act of 1965, which is why we stop the analysis of such vote shares at that time.
}

trend, we calculate the effect of a 25 percentage point increase in 1860 slavery on the presidential vote in each year. Thus, each point in figure 4 represents a (scaled) point estimate from a regression of county-level Democratic vote share on county proportion slave in 1860 , using the same cotton-suitability IV design as table $2 .{ }^{25}$ As the figure shows, there is little difference between slave and nonslave areas before the Civil War, with the exception of 1856, where, if anything, high-slave areas are more likely to vote for the more moderate candidate on slavery, former president Millard Fillmore (compared to the relatively more pro-slavery Democratic candidate James Buchanan). Thus, at least in terms of national party politics, differences in white views appear to organize around the density of slavery more strongly after the Civil War. ${ }^{26}$

Instead, as figure 4 indicates, the data show that regional differences emerged after the end of Reconstruction. As white elites begin to restrict the vote of African Americans in the late nineteenth century, the effect of slavery increases, reaching its peak around the time that most of the states finalized the enactment of poll taxes and literacy tests to almost fully disenfranchise blacks (Kousser 1974). By around 1950, the effect of slavery weakens, in part due to some small additions of African Americans to the registered voter pool, ${ }^{27}$ and also to the move of national Democratic candidates toward a civil rights platform. The effect sizes from the 1950s and 1960s are roughly similar in magnitude, but in the opposite direction, to the effect of slavery on the Obama white vote in 2008, estimated from CCES white respondents. Throughout, the difference in voting behavior between formerly large slaveholding counties and other counties is large and statistically significant. These findings also hold if we use the WLS specification and condition on our pretreatment covariates, and they hold even when we control for county-level vote for Democrat James Buchanan in the 1856 presidential election. These findings suggest that large and significant differences in partisanship emerge in the postbellum period even among counties that were politically and economically similar in the antebellum period. Furthermore, they reinforce the historical account of Foner (2011, 11-18), who describes how the Civil War am-

25. We use the original 1860 county boundaries for the measurement of slavery for outcomes until 1924, after which we use the data interpolated to modern boundaries. The changes in county boundaries between 1924 and today in the sample states is minimal.

26. We obtain similar results for congressional elections and using the WLS specification.

27. The percentage of the black voting-age population expanded from $3 \%$ to $18 \%$ in Georgia and from $0.8 \%$ to $13 \%$ in South Carolina (Mickey 2015). 


\section{Presidential Elections}

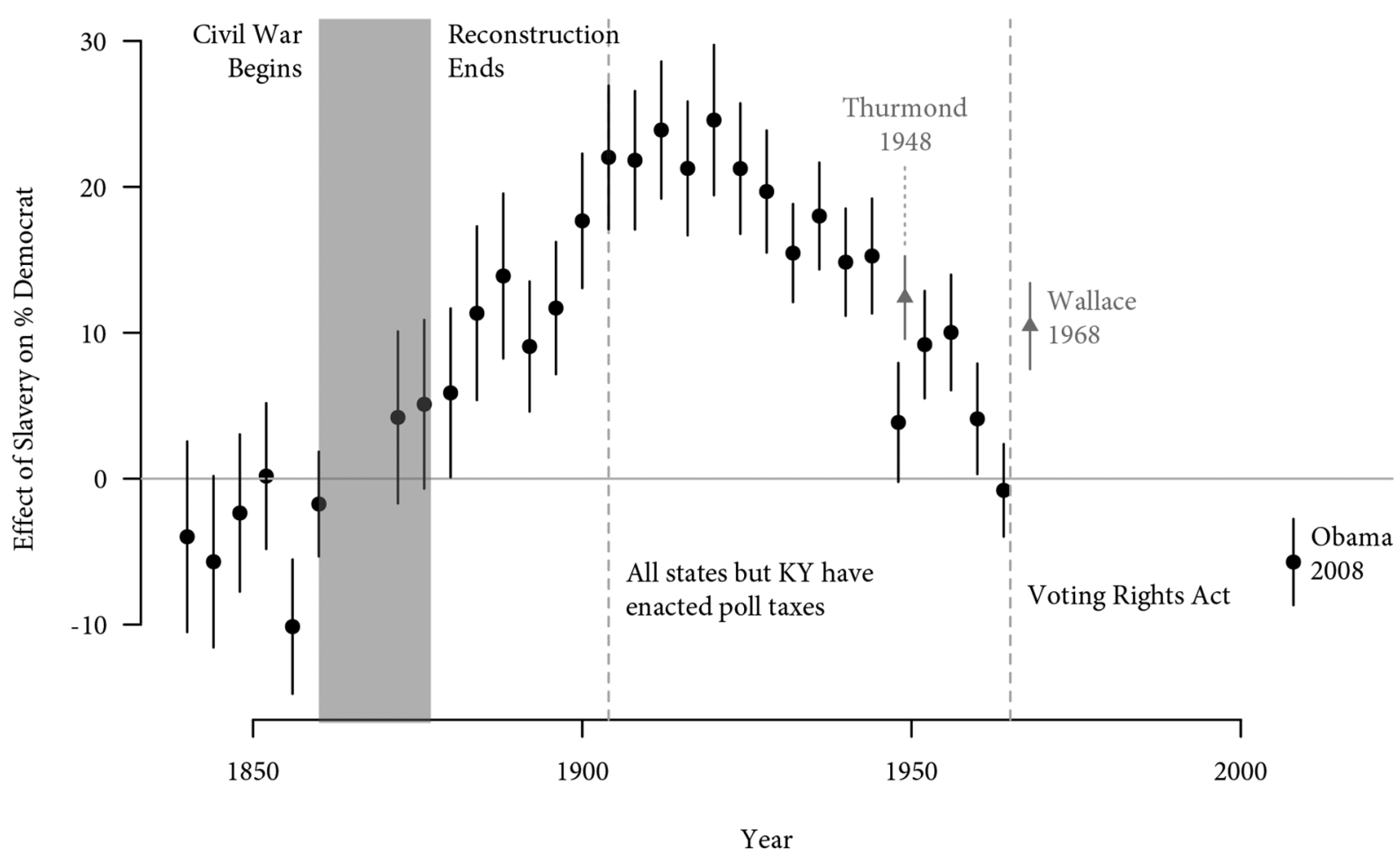

Figure 4. Effect of proportion slave on vote for Democratic presidential candidate in the South over time. Each point is the effect of a 25 percentage point increase in proportion slave from separate IV models of county-level Democratic share of the presidential vote on proportion slave. Results for Obama in 2008 are from white respondents in the CCES.

plified divisions and resentments within the white Southern population, concluding that "the [Civil War] redrew the economic and political map of the white South" (17).

However, regarding antebellum differences, we note that presidential election results in the prewar period could be masking important intraregional differences, especially since the Second Party system attempted to remove slavery as an issue in national politics. For a stronger test of the effect of slavery on antebellum politics, we turn to two state-level elections that centered on slavery and sectional issues. Specifically, after the Compromise of 1850, many states in the South were divided over the deal's fairness and whether to extend popular sovereignty to the territories. The deal, which admitted California as a free state, proved so unpopular that several gubernatorial elections in 1851 pitted states' rights extremists, who openly discussed secession, against more moderate Unionist candidates, who supported the compromise (Holt 1999, 605-9). In Georgia, for example, Constitutional Union candidate Howell Cobb ran against former Governor and Southern Rights candidate Charles McDonald, and, in Mississippi, moderate Senator Henry Foote ran against former Senator (and future Confederate President) Jefferson Davis. These elections provided the (white) electorate a clear choice in the na- tional fight over slavery and could potentially reveal antebellum regional differences on the issue. Figure 5 presents the relationship between slavery in 1850 and county-level vote shares for the moderate candidates. In both states, perhaps surprisingly, there is little evidence of a strong relationship between slavery and vote choice, even in an election that focused so heavily on the issue. Low-slave areas were not actively anti-slavery and did not appear to actively resist secession in the early 1850s. Furthermore, the high-slave areas were at least as willing to compromise on the issue of slavery, suggesting that the contemporary political geography of slavery probably does not trace its origins to this time period.

\section{Lynchings and other forms of suppression}

Our incentives-based mechanism posits that violence was used not only to disenfranchise blacks but also to suppress their mobility and wages - a particularly strong incentive in the post-war, post-emancipation period. If the mechanism is at play, then we would expect to see greater racist violence in former slaveholding counties in this time period. While we do not have measures of all forms of violent racism in the post-Reconstruction Era, we do have county- 


\section{Georgia Gubernatorial Election, 1851}

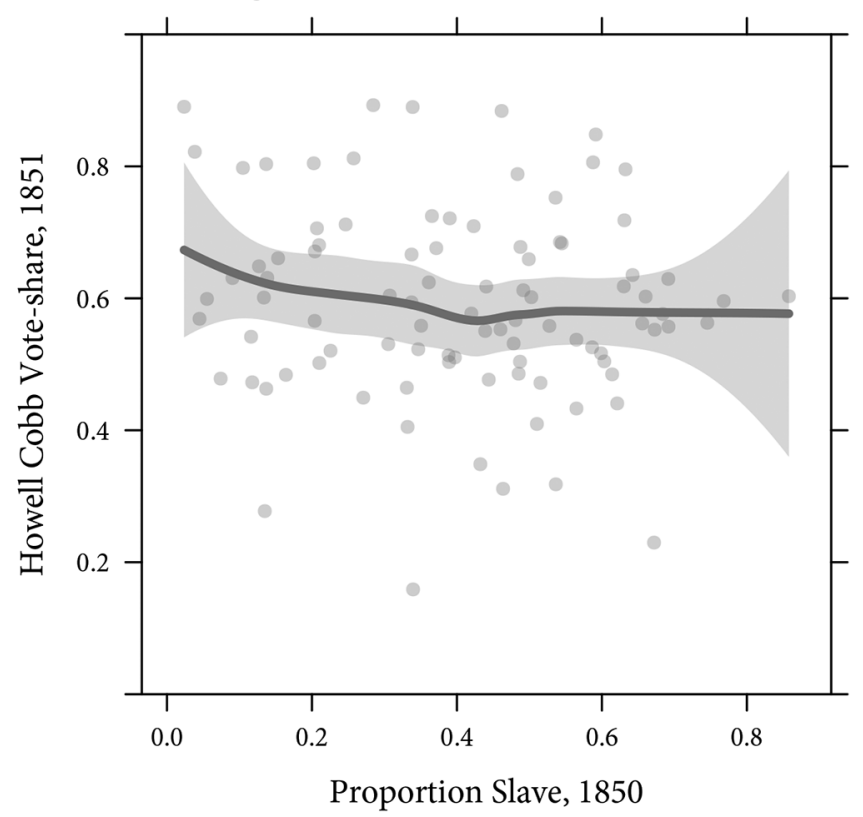

Mississippi Gubernatorial Election, 1851

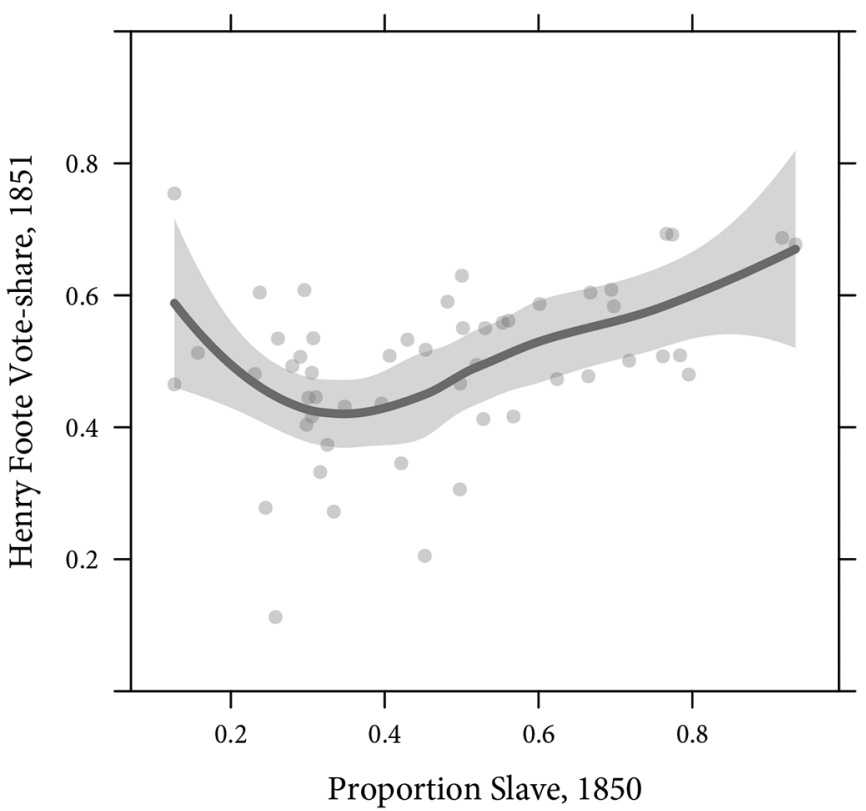

Figure 5. Within-state relationship between proportion slave in 1850 in a county and percentage voting for Unionist candidates in 1851 in that county. Both Howell Cobb and Henry Foote were running against strong States' Rights supporters in the aftermath of the Compromise of 1850 . Higher values on each $y$-axis indicate more moderate voting with regard to slavery and secession.

level measures of one extreme form of racial violence: lynchings (Beck and Tolnay 2004). ${ }^{28}$

In column 1 of table 5 , we confirm the hypothesis that the number of black lynchings between 1882 and 1930 per 100,0001920 residents is greater in counties that had high slave proportions in 1860, conditional on state-level fixed effects and our 1860 covariates. The effect of slavery in 1860 and lynchings in this period is large and significant: a 10 percentage point increase in slave proportion is associated with a 1.89 increase in lynchings per 100,000 residents. This result is in line with our incentive-based theory: there is more racial violence in areas previously more reliant on slave labor. Furthermore, if our explanation is correct, then black farmers should be worse off in former slave areas due to this greater local violence. Appendix table A.17 draws on data from the the 1925 Agricultural Census (Haines 2010) and shows that, in comparison to white farmers, black farmers in former high-slave areas were significantly worse off than those in other areas of the South. They were more likely to be under tenancy agreements and less likely to own their own farm.

\section{Mechanization of Southern agriculture}

After slaves were freed, Southern elites used various tactics to gain an advantage in the market for black labor, including racial violence, convict leasing, anti-vagrancy laws,

28. These data include all states in our analysis except Texas, Virginia, and West Virginia. and anti-enticement laws (Ransom and Sutch 2001). A clear implication of our incentives-based mechanism is that once the demand for black labor drops due to exogenous technological development, the incentives for whites to interfere in the labor market with such tactics should lessen, and thus the effects of slavery on attitudes should also diminish. This implication is testable given that much of the Southern economy was agricultural, and its main cash crop, cotton, was heavily labor intensive until about the 1930s when Southern agriculture started to mechanize and tractors began to replace labor.

To test this, we examine whether counties that mechanized earlier are indeed those where the effects of slavery wanes more quickly. Following Hornbeck and Naidu (2014), we use the number of farming tractors as a proxy for mechanization. ${ }^{29}$ We interact the proportion of slaves in 1860 with the change in the number of tractors per 100,000 acres of agricultural land in the county between 1930 and 1940, which we collect from the 1930 and 1940 Agricultural Censuses (Haines 2010). We then estimate the effect of this interaction on our three outcome measures. As table 5 shows, the effects of slavery are weaker for counties where mechanization grew between 1930 and 1940. For example,

29. Tractors were an early form of mechanization for the cotton industry, intended to replace mule-drawn plows (Wiener 1978). Full-blown mechanization of cotton production via the cotton picker would not become widespread until after 1940. 
Table 5. Effect of Slavery on Postbellum Violence and Effect Modification by Mechanization

\begin{tabular}{|c|c|c|c|c|}
\hline & $\begin{array}{l}\text { Lynchings } \\
\text { (1) }\end{array}$ & $\begin{array}{l}\text { Proportion Democrat } \\
\text { (2) }\end{array}$ & $\begin{array}{l}\text { Affirmative Action } \\
\text { (3) }\end{array}$ & $\begin{array}{c}\text { Racial Resentment } \\
\text { (4) }\end{array}$ \\
\hline Proportion slave, 1860 & $\begin{array}{l}17.656^{* *} \\
(5.661)\end{array}$ & $\begin{array}{c}-.183^{\star *} \\
(.049)\end{array}$ & $\begin{array}{l}-.219^{\star *} \\
(.042)\end{array}$ & $\begin{array}{l}.703^{\star *} \\
(.161)\end{array}$ \\
\hline Tractors change, $1930-40$ & & $\begin{array}{r}-.417^{+} \\
(.243)\end{array}$ & $\begin{array}{l}-.629^{* *} \\
(.207)\end{array}$ & $\begin{array}{l}2.290^{* *} \\
(.791)\end{array}$ \\
\hline Proportion slave $\times$ tractors change & & $\begin{array}{l}2.298^{* *} \\
(.868)\end{array}$ & $\begin{array}{l}2.226^{* *} \\
(.741)\end{array}$ & $\begin{array}{l}-7.762^{\star *} \\
(2.876)\end{array}$ \\
\hline State-year fixed effects & $\begin{array}{l}\sqrt{ } \\
\sqrt{ }\end{array}$ & $\sqrt{ }$ & $\sqrt{ }$ & $\sqrt{ }$ \\
\hline$N$ & 910 & 1,145 & 1,145 & 1,020 \\
\hline$R^{2}$ & .350 & .208 & .104 & .152 \\
\hline Specification & WLS-county area & WLS-sample size & WLS-sample size & WLS-sample size \\
\hline
\end{tabular}

Note. The first column is weighted least squares (WLS) with the total county area as weights (and where county area is omitted from the 1860 covariates, though this has no effect on our analysis). The remaining columns are WLS with within-county sample size as weights. Lynchings are black lynchings between 1882 and 1930 per 100,000 1920 residents (similar results hold using average population size between these dates). Tractors change is the change in tractors per 100,000 acres of land between 1930 and 1940. Tractors in 1930 is the number of tractors per 100,000 acres of land in 1930 .

$+p<.10$.

${ }^{*} p<.05$.

${ }^{* *} p<.01$.

where mechanization did not grow between 1930 and 1940, a 10 percentage point increase in proportion slave leads to a 1.8 percentage point drop in the percent of whites who identify as Democrat today ( $95 \%$ confidence interval: $[-2.7,-1.0])$. Where mechanization grew rapidly, with 0.06 more tractors per 100,000 acres (90th percentile), the same change in proportion slave leads to only a 0.2 percentage point decrease in the percent Democrat $(95 \%$ confidence interval: $[-1.1,0.06])$.

We note two potential concerns with this test. First, the results could be consistent with a racial threat explanation-early mechanization led to decreases in the black population in these areas (as shown by Hornbeck and Naidu 2014). In appendix table A.16, however, we replicate the analysis using the declines in proportion black from 1920 to 1940 and 1970 and find that areas with larger declines have, if anything, larger effects associated with slavery. Thus, it seems unlikely that dimishing racial threat is driving the attenuating effects we see above. Second, it could be that more racially tolerant counties chose to mechanize early in order to rid themselves of the incentives for racial exploitation. However, as shown in appendix table A.18, there is no relationship between growth in tractors and either racial violence or inequality in wages between blacks and whites. This casts doubt that tractors or their growth are indicators of racial attitudes. Moreover, as Hornbeck and Naidu (2014) argue, many of the counties that mechanized early were those affected by an exogenous shock, that of the Mississippi floods of 1927 , and are thus ex ante similar to counties that mechanized later.

\section{Intergenerational transmission of beliefs}

Our last empirical analysis concerns the intergenerational transfer of political attitudes - or, how attitudes on politics and race have been passed down over time. One possibility is that attitudes are shaped contemporaneously by local institutions, for example, schools and churches, which have themselves persisted. Another possibility is that these attitudes have been passed down from parents to children, perhaps within a broader context of institutions, but also through intergenerational socialization. Both transmission mechanisms are likely at play, and finding correlated attitudes between parents and children would be consistent with research in political science demonstrating the importance of parents' partisanship in shaping children's partisanship (e.g., Campbell et al. 1980; Jennings and Niemi 1968).

To explore the inheritance of racial attitudes from previous generations, we rely on the Youth-Parent Socialization Panel Survey, which measured the racial attitudes of a national probability sample of high school senior students in 1965 along with their parents (Elliot 2007; Jennings et al. 2005). This study followed up with the students and interviewed them in 1973, 1982, and 1997, with response rates over $80 \%$ in each survey wave. We focus on the subset of this sample who lived in the South in $1965(n=241)$, 
which is a good proxy for students who were raised in the South. ${ }^{30}$ If attitudes are being passed down from generation to generation, then we would expect that the racial attitudes of parents in 1965 should be correlated with the views of their children in each wave of the survey. We measure racial views in these surveys as the difference between the thermometer score for whites and the thermometer score for blacks, which is available for both parents and children in each wave. Figure 6 shows these correlations for each wave and demonstrates how stable this relationship is over time. What these correlations show is that children with racially conservative parents in 1965 are more likely to be racially conservative themselves at least through age 50, which is evidence of intergenerational socialization.

A final concern is that our findings regarding contemporary attitudes may be driven not by intergenerational transmission but by the direct experiences and attitudes of older individuals in our CCES sample. That is, we are detecting an effect only among older whites, which would suggest no or limited intergenerational transfer of attitudes and instead an exposure to the tail end of Jim Crow. To test this, we estimate the effect among a subgroup who were more likely to receive such attitudes only from their parents: whites born after the Civil Rights Act of 1964 and the Voting Rights Act of 1965. While segregation and race-related oppression extended well past this time, both pieces of legislation have been acknowledged as influential in strongly reducing segregation in the South and increasing black enfranchisement (Rosenberg 2008). In table 6, we show the effect of slavery on these younger whites is just as strong and statistically significant as it is for older whites. Together with our results on racial threat and income-based discrimination, these findings provide some evidence that the parent-to-child transmission mechanism is an important component of how slavery affects attitudes. As such, this evidence provides some support that political culture, rather than exclusively institutions, plays an important role in explaining the persistent effects of American slavery.

\section{CONCLUSION}

In this paper, we have shown that an institution that was formally abolished 150 years ago still has effects on attitudes today. Specifically, we show that American slavery has had a direct impact on Southern whites' (i) partisan identification, (ii) attitudes on affirmative action, (iii) levels of racial resentment, and (iv) attitudes toward blacks. We further

30. See Jennings, Stoker, and Bowers (2009), for a fuller analysis of the national results from this panel survey. showed that our findings are robust to instrumenting for cotton suitability, lending credibility that our estimates are causal. Our findings are robust to accounting for a wide variety of factors that could plausibly affect both the share of the population that was enslaved and also contemporary political attitudes. In addition, we ruled out several contemporary-based explanations. Specifically, we ruled out the theory of "racial threat," or the idea that contemporary shares of the black (minority) population are what drive white (majority) group racial attitudes. When we took into account contemporary shares of the black population using appropriate methods, we found that slavery continues to have a separate direct effect. We also provided suggestive evidence that our results are not due exclusively to geographic mobility over the course of the twentieth century, nor are they due to contemporary income inequality between blacks and whites.

Our results instead suggest a separate causal channel attributable to the historical persistence of regional variation in attitudes that was amplified by post-Civil War events. The years during and after the Reconstruction Period saw whites coordinating to provide an informal social infrastructure (and to the extent legally permissible an institutional one as well) to maintain as much as possible the economic and political power previously guaranteed to them under slavery. As affirmative support, we showed that greater prevalence of slavery predicts more conservative (for many years more Democratic) presidential vote shares, higher rates of radical violence, and decreased wealth concentrated in black farms in the decades after Reconstruction. We also showed that the long-term effects of slavery are smaller in

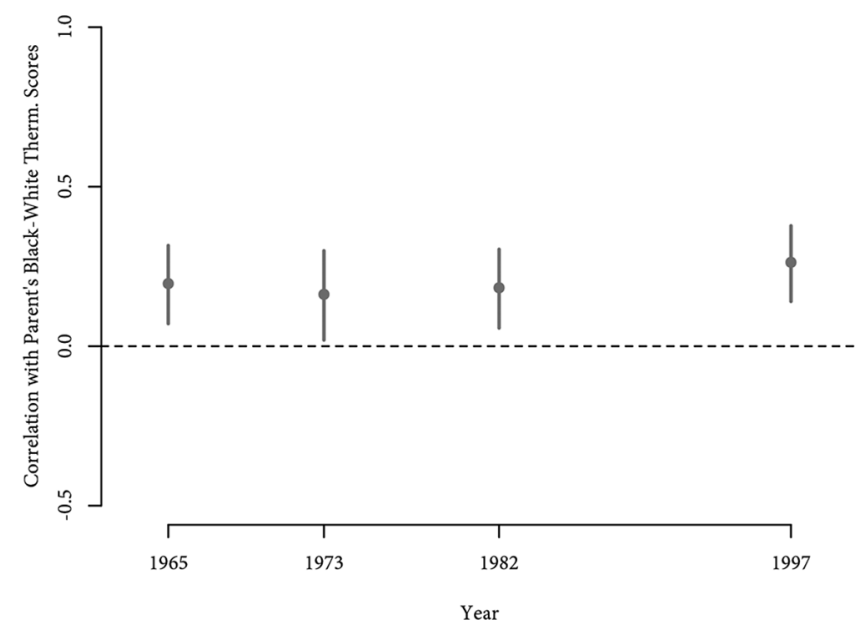

Figure 6. Correlation coefficients between parent's white racial preference in 1965 and their children's white racial preference measured at four time periods: 1965, 1973, 1982, and 1997. White racial preference here is measured as the difference between the respondent's thermometer scores for white and black people. 
Table 6. Effects of Slavery for Those Born after the Voting Rights Act

Proportion Democrat Logistic

(1)

Affirmative Action Logistic

(2)

$-.840^{*}$
$(.358)$
$\sqrt{ }$
$\sqrt{ }$
9,528

$-1.113^{* *}$

$(.365)$

$\sqrt{ }$

9,551
Racial Resentment OLS

(3)

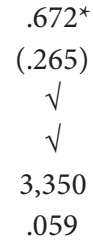

Note. All models are at the individual level, with standard errors, in parentheses, clustered on county and weighted by CCES survey weights. $* p<.05$.

${ }^{* *} p<.01$.

areas of the US South that were quick to mechanize in the early to mid-twentieth century. Finally, we also offered evidence that parent-to-child transmission could be an important mechanism by which attitudes have been passed down over time. However, we do not rule out that Southern institutions may have also played an important role.

Our research has substantial implications for our understanding and study of politics. Much work within political science, and on public opinion specifically, focuses on contemporary respondent factors, such as income, age, gender, education, and so on, in trying to explain contemporary public opinion. However, this style of research overlooks historical and culturally rooted explanations for the formation of public opinion. Our findings here suggest that historical institutions like slavery are significant in shaping American culture and politics, even if they no longer exist. In light of this, the field of political behavior could benefit from exploring other potential relationships between historical forces and contemporary attitudes. As Key $(1949,6)$ himself observed, social and historical forces have "an impact on political habit whose influence has not worn away even yet." This might be the case not just for development of political attitudes in the US South but also in other arenas within American politics and elsewhere in the world.

\section{ACKNOWLEDGMENTS}

We thank Stephen Ansolabehere, Larry Bartels, David Broockman, Cathy Cohen, Stanley Engerman, Gerald Gamm, Hein Goemans, Justin Grimmer, Steven Hahn, Jeff Jenkins, Gary King, George Krause, Chyrl Laird, Corrine McConnaughy, Marc Meredith, Robert Mickey, Clayton Nall, Suresh Naidu, Dianne Pinderhughes, Kevin Quinn, Karthick Ramakrishnan, Marc Ratkovic, John Roemer, Daria Roithmayr, Cyrus Samii, Eric Schickler, Ken Shotts, Adam Slez, Paul Sniderman, Brandon Stewart, Michael Tesler, Vesla Weaver, Jon Woon, and seminar participants at Boston University, Columbia, Dartmouth, Harvard Kennedy School, Harvard Law School, Notre Dame, Princeton, Rochester, Stanford, Warwick, University of California, Berkeley, University of California, Riverside, University of Pennsylvania, University of Pittsburg, Washington University-St. Louis, University of Southern California, and University of Virginia for comments and suggestions. We are also grateful to Michael Haines, Eitan Hersh, and Heather O'Connell for sharing data with us.

\section{REFERENCES}

Acemoglu, Daron, Davide Cantoni, Simon Johnson, and James A. Robinson. 2011. "The Consequences of Radical Reform: The French Revolution.” American Economic Review 101 (7): 3286-3307.

Acemoglu, Daron, Camilo García-Jimeno, and James A. Robinson. 2012. "Finding Eldorado: Slavery and Long-Run Development in Colombia." Journal of Comparative Economics 40 (4): 534-64.

Acharya, Avidit, Matthew Blackwell, and Maya Sen. 2015. "Explaining Attitudes from Behavior: A Cognitive Dissonance Approach.” HKS Faculty Research Working paper RWP14-026, Harvard Kennedy School, Harvard University.

Acharya, Avidit, Matthew Blackwell, and Maya Sen. Forthcoming. "Explaining Causal Findings without Bias: Detecting and Assessing Direct Effects." American Political Science Review. http://www.matt blackwell.org/files/papers/direct-effects.pdf.

Alston, Lee J., and Joseph P. Ferrie. 1993. "Paternalism in Agricultural Labor Contracts in the U.S. South: Implications for the Growth of the Welfare State.” American Economic Review 83 (4): 852-76.

Ansolabehere, Stephen. 2010. "Cooperative Congressional Election Study, 2010: Common Content.” Harvard University [producer]. http://projects .iq.harvarfd,edu/cces/.

Beck, E. M., and Stewart E. Tolnay. 2004. "Confirmed Inventory of Southern Lynch Victims, 1882-1930.” Data file available from authors.

Becker, Gary S. 2010. The Economics of Discrimination. Chicago: University of Chicago Press.

Bisin, Alberto, and Thierry Verdier. 2000. "A Model of Cultural Transmission, Voting and Political Ideology." European Journal of Political Economy 16 (1): 5-29.

Black, Earl, and Merle Black. 1987. Politics and Society in the South. Cambridge, MA: Harvard University Press. 
640 / The Political Legacy of American Slavery Avidit Acharya, Matthew Blackwell, and Maya Sen

Blackmon, Douglas A. 2008. Slavery by Another Name: The Re-enslavement of Black Americans from the Civil War to World War II. New York: Anchor Books.

Blalock, Hubert M. 1967. Toward a Theory of Minority-Group Relations Hoboken, NJ: Wiley.

Blumer, Herbert. 1958. "Race Prejudice as a Sense of Group Position." Pacific Sociological Review 1 (1): 3-7.

Boyd, Robert, and Peter J. Richerson. 1988. Culture and the Evolutionary Process. Chicago: University of Chicago Press.

Campbell, Angus, Philip E. Converse, Warren E. Miller, and Donald E. Stokes. 1980. The American Voter. Chicago: University of Chicago Press.

Carmines, Edward G., and James A. Stimson. 1989. Issue Evolution: Race and the Transformation of American Politics. Princeton, NJ: Princeton University Press.

Dell, Melissa. 2010. “The Persistent Effects of Peru's Mining Mita." Econometrica 78 (6): 1863-1903.

Du Bois, W. E. B. 1935. Black Reconstruction in America, 1860-1880. New York: Free Press

Elliot, Patrick. 2007. “Three Generations Combined, 1965-1997.” Interuniversity Consortium for Political and Social Research (ICPSR). http://doi.org/10.3886/ICPSR04532.v1.

Faust, Drew Gilpin. 1988. The Creation of Confederate Nationalism: Ideology and Identity in the Civil War South. Baton Rouge: Louisiana State University Press.

Festinger, Leon. 1957. A Theory of Cognitive Dissonance. Stanford, CA: Stanford University Press.

Foner, Eric. 2011. Reconstruction: America's Unfinished Revolution, 18631877. New York: Harper \& Row.

Gilens, Martin. 2009. Why Americans Hate Welfare: Race, Media, and the Politics of Antipoverty Policy. Chicago: University of Chicago Press.

Giles, Micheal W. 1977. "Percent Black and Racial Hostility: An Old Assumption Reexamined.” Social Science Quarterly 58 (3): 412-17.

Giles, Micheal W., and Melanie A. Buckner. 1993. "David Duke and Black Threat: An Old Hypothesis Revisited." Journal of Politics 55 (3): 702-13.

Glaser, James M. 1994. "Back to the Black Belt: Racial Environment and White Racial Attitudes in the South." Journal of Politics 56 (1): 21-41.

Green, Donald P., and Lynn Vavreck. 2008. “Analysis of Cluster-Randomized Experiments: A Comparison of Alternative Estimation Approaches.” Political Analysis 16 (2): 138-52. http://pan.oxfordjournals.org/content/16/2 138.abstract.

Haines, Michael R. 2010. "Historical, Demographic, Economic, and Social Data: The United States, 1790-2002.” Inter-university Consortium for Political and Social Research (ICPSR) [distributor]. http://www.icpsr .umich.edu/icpsrweb/ICPSR/studies/2896.

Higgs, Robert. 1977. Competition and Coercion: Blacks in the American Economy, 1865-1914. Cambridge: Cambridge University Press.

Holt, Michael F. 1999. The Rise and Fall of the American Whig Party: Jacksonian Politics and the Onset of the Civil War. Oxford: Oxford University Press.

Hopkins, Daniel J. 2010. "Politicized Places: Explaining Where and When Immigrants Provoke Local Opposition." American Political Science Review 104 (1): 40-60.

Hornbeck, Richard, and Suresh Naidu. 2014. "When the Levee Breaks: Black Migration and Economic Development in the American South." American Economic Review 104 (3): 963-90

Imai, Kosuke, Luke Keele, Dustin Tingley, and Teppei Yamamoto. 2011. "Unpacking the Black Box of Causality: Learning about Causal Mechanisms from Experimental and Observational Studies." American Political Science Review 105 (4): 765-89.

Jennings, M. Kent, Gregory B. Markus, Richard G. Niemi, and Laura Stoker. 2005. "Youth-Parent Socialization Panel Study, 1965-1997:
Four Waves Combined." Inter-university Consortium for Political and Social Research (ICPSR). Data set. http://doi.org/10.3886/ICPSR04037.v1. Jennings, M. Kent, and Richard G. Niemi. 1968. "The Transmission of Political Values from Parent to Child." American Political Science Review 62 (1): 169-84.

Jennings, M. Kent, Laura Stoker, and Jake Bowers. 2009. "Politics across Generations: Family Transmission Reexamined." Journal of Politics 71 (3): 782-99.

Katznelson, Ira, Kim Geiger, and Daniel Kryder. 1993. "Limiting Lliberalism: The Southern Veto in Congress, 1933-1950." Political Science Quarterly 108 (2): 283-306.

Key, V. O. 1949. Southern Politics in State and Nation. New York: Knopf. Kinder, Donald R., and David O. Sears. 1981. "Prejudice and Politics: Symbolic Racism versus Racial Threats to the Good Life." Journal of Personality and Social Psychology 40 (3): 414-31.

Kousser, Morgan J. 1974. The Shaping of Southern Politics: Suffrage Restriction and the Establishment of the One-Party South, 1880-1910. New Haven, CT: Yale University Press.

Kuziemko, Ilyana, and Ebonya Washington. 2015. "Why Did the Democrats Lose the South? Bringing New Data to an Old Debate." Working paper no. 21703, National Bureau of Economic Research, Cambridge, MA.

Lagerlöf, Nils-Petter. 2005. "Geography, Institutions, and Growth: The United States as a Microcosm." Working paper, Department of Economics, York University, Toronto.

Lee, Woojin, and John E. Roemer. 2006. "Racism and Redistribution in the United States: A Solution to the Problem of American Exceptionalism." Journal of Public Economics 90 (6): 1027-52.

Lichtenstein, Alex. 1996. Twice the Work of Free Labor: The Political Economy of Convict Labor in the New South. Brooklyn, NY: Verso.

Logan, Rayford W. 1954. The Negro in American Life and Thought. New York: Dial

Markus, Gregory B., and Philip E. Converse. 1979. "A Dynamic Simultaneous Equation Model of Electoral Choice." American Political Science Review 73 (4): 1055-70.

Mickey, Robert. 2015. Paths out of Dixie: The Democratization of Authoritarian Enclaves in America's Deep South, 1944-1972. Princeton, NJ: Princeton University Press.

Mitchener, Kris James, and Ian W. McLean. 2003. "The Productivity of U.S. States since 1880." Journal of Economic Growth 8 (1): 73-114.

Nunn, Nathan. 2008. "Slavery, Inequality, and Economic Development in the Americas.” In Elhanan Helpman, ed., Institutions and Economic Performance. Cambridge, MA: Harvard University Press.

Nunn, Nathan. 2009. "The Importance of History for Economic Development.” Annual Review of Economics 1 (1): 65-92.

Nunn, Nathan, and Leonard Wantchekon. 2011. "The Slave Trade and the Origins of Mistrust in Africa." American Economic Review 101 (7): 3221-52.

O'Connell, Heather A. 2012. “The Impact of Slavery on Racial Inequality in Poverty in the Contemporary U.S. South.” Social Forces 90 (3): 713 34.

Ogburn, William F., and Charles M. Grigg. 1956. "Factors Related to the Virginia Vote on Segregation.” Social Forces 34 (4): 301-8.

Oliver, J. Eric, and Tali Mendelberg. 2000. "Reconsidering the Environmental Determinants of White Racial Attitudes." American Journal of Political Science 44:574-89.

Pierson, Paul. 2000. "Increasing Returns, Path Dependence, and the Study of Politics." American Political Science Review 94 (2): 251-67.

Ransom, Roger L., and Richard Sutch. 2001. One Kind of Freedom: The Economic Consequences of Emancipation. Cambridge: Cambridge University Press 
Reed, John Shelton. 1972. "Percent Black and Lynching: A Test of Blalock's Theory." Social Forces 50 (3): 356-60.

Roithmayr, Daria. 2010. "Racial Cartels." Michigan Journal of Race and Law 16 (1): 45-79.

Rosenbaum, Paul R. 1984. "The Consquences of Adjustment for a Concomitant Variable That Has Been Affected by the Treatment." Journal of the Royal Statistical Society: Series A (General) 147 (5): 656-66.

Rosenberg, Gerald N. 2008. The Hollow Hope: Can Courts Bring about Social Change? Chicago: University of Chicago Press.

Ruggles, Steven, J. Trent Alexander, Katie Genadek, Ronald Goeken, Matthew B. Schroeder, and Matthew Sobek. 2010. "Integrated Public Use Microdata Series: Version 5.0" [Machine-readable database].

Valentino, Nicholas A., and David O. Sears. 2005. "Old Times There Are Not Forgotten: Race and Partisan Realignment in the Contemporary South." American Journal of Political Science 49 (3): 67288.

Vansteelandt, Sijn. 2009. "Estimating Direct Effects in Cohort and CaseControl Studies." Epidemiology 20 (6): 851-60.
Voigtländer, Nico, and Hans-Joachim Voth. 2012. "Persecution Perpetuated: The Medieval Origins of Anti-Semitic Violence in Nazi Germany." Quarterly Journal of Economics 127 (3): 1339-92.

Voss, D. Stephen. 1996. "Beyond Racial Threat: Failure of an Old Hypothesis in the New South." Journal of Politics 58 (4): 1156-70.

Wiener, Jonathan M. 1978. Social Origins of the New South: Alabama, 1860-1885. Baton Rouge: Louisiana State University Press.

Wilcox, Clyde, Lee Sigelman, and Elizabeth Cook. 1989. "Some Like It Hot: Individual Differences in Responses to Group Feeling Thermometers." Public Opinion Quarterly 53 (2): 246-57.

Woodward, C. Vann. (1955) 2002. The Strange Career of Jim Crow. Oxford: Oxford University Press.

Wright, Gavin. 1986. Old South, New South: Revolutions in the Southern Economy Since the Civil War. Vol. 2. New York: Basic Books.

Wright, Gerald C., Jr. 1977. "Contextual Models of Electoral Behavior: The Southern Wallace Vote." American Political Science Review 71 (2): 497-508.

Zaller, John. 1992. The Nature and Origins of Mass Opinion. Cambridge: Cambridge University Press. 